\title{
Scale-related seabird-environmental relationships in Pacific equatorial waters, with reference to El Niño-Southern Oscillation events
}

\author{
Christine A. Ribic ${ }^{1, *}$, David G. Ainley ${ }^{2}$, Larry B. Spear ${ }^{2}$ \\ ${ }^{1}$ USGS BRD Wisconsin Cooperative Wildlife Research Unit, Department of Wildlife Ecology, 226 Russell Labs, \\ University of Wisconsin, Madison, Wisconsin 53706-1598, USA \\ ${ }^{2}$ H. T. Harvey \& Associates, 906 Elizabeth St., PO Box 1180, Alviso, California 95002, USA
}

\begin{abstract}
We assessed the spatial scales at which variability in ocean climate could affect habitat associations of tropical seabirds and whether species-environmental variable relationships at the smallest scale provide insight into occurrence patterns at larger scales. In the eastern tropical Pacific $\left(10^{\circ} \mathrm{N}\right.$ to $10^{\circ} \mathrm{S}$ and $140^{\circ}$ to $90^{\circ} \mathrm{W}$ ), seabirds were censused on 16 cruises that followed the same tracks every spring and autumn, 1984 to 1991. This study area possesses closely spaced, well-defined water types and the time period was sufficient to include 2 ENSOs (El Niño-Southern Oscillation) and 1 cold water event (LNSO), thus insuring maximum environmental variability. On the cruises, we measured physical features such as sea-surface temperature (SST) and salinity (SSS) at a coarse scale (1 to $100 \mathrm{~km})$ as well as, at the large scale, the identity of surface water masses and current systems. During spring, at the coarse scale, seabirds were associated mainly with a canonical axis consisting of SST and SSS. During autumn, coarse scale seabird/environment associations were defined by a canonical axis composed of SST and thermocline depth; SSS was of secondary importance. Using SST and SSS optima from the coarse scale analysis, we could predict only the water mass associations for individual species during spring. Consistent between-year associations with water masses were not found in either season. Regardless of season, seabirds at the large scale were associated most consistently with current systems rather than water masses. At the coarse scale, neither the canonical axes nor the seabird associations with these axes were affected by ENSO/LNSO events. At the large scale, seabird associations with currents remained the same during the ENSO/LNSO events for sooty tern, black-winged and white-winged petrels, and wedge-tailed shearwater. Juan Fernandez petrel, wedge-rumped stormpetrel, and Leach's storm-petrel had different associations with currents during the ENSO/LNSO events. We hypothesize that the effect of ENSO/LNSO events on individual species is mitigated by the ability of species to persist in low productivity waters during the non-ENSO/LNSO years.
\end{abstract}

KEY WORDS: Seabirds . Eastern tropical Pacific - Water masses Currents - El Niño-Southern Oscillation Species-habitat relationships

\section{INTRODUCTION}

In tropical and subtropical portions of the world ocean, research on the association of seabirds with environmental factors has been concentrated at the course and mesoscale levels, e.g. studies of frontal eddies in the Gulf Stream, Atlantic Ocean (Haney

•E-mail: caribic@facstaff.wisc.edu
1986), and environmentally mediated associations of birds, cetaceans and tuna in the Pacific Ocean (Au \& Pitman 1986, 1988, Ballance 1993, Ballance et al. 1997). Work at larger scales has progressed on relationships of seabirds to latitudinal gradients in sea-surface temperature (SST), salinity (SSS; Ainley \& Boekelheide 1983, Ribic \& Ainley 1988/89) and other factors in the Pacific (Spear et al. 1995); longitudinal gradients in thermocline depth as they affect feeding flocks in the Pacific (Ballance et al. 1997); and associations of 
seabirds with water masses in the Indian Ocean (Pocklington 1979). Thus, there exists a mix of studies at different spatial and temporal scales on the relationship of seabird habitat features in tropical oceans.

In general, research on the habitat relationships of tropical seabirds has been far less common than on seabirds of polar, subpolar and eastern-boundary current regions. For example, 2 summary volumes are available on the marine ecology of seabirds. The one edited by Nettleship et al. (1985) contains 23 chapters but none on tropical seabirds and the one edited by Croxall (1987) contains 14 chapters with only 2 on tropical species. In Hunt \& Schneider's (1987) review of the marine environmental processes that affect seabirds, only 22 of the 115 titles reviewed on seabirds concerned tropical species and many not exclusively. In light of this, we thought that the study of tropical seabirds, and particularly those of the eastern tropical Pacific (ETP), our study area, would offer unusual opportunities to understand how oceanic factors affect tropical seabird occurrence. First, seasonal change in oceanic properties of tropical systems are minimal compared to northern latitudes. Second, tropical avifaunas are comprised mostly of resident species in stark contrast to the enormous seasonal flux of species in cooler waters. Third, several water types in the ETP are well defined and closely spaced. Fourth, few breeding sites exist in the ETP, thus precluding the occurrence of birds commuting over waters with which they are not ecologically associated. Finally, the wellstudied phenomenon known as El Niño-Southern Oscillation (ENSO) perturbs the ETP on a frequent basis.

Our aim in this study was to bridge the various studies of habitat relationships of tropical species by looking at more than 1 scale simultaneously and using relationships at the smallest scale to understand those at larger scales. We also experimented with various analytical techniques to best address this problem. Coincidental to our work, and certainly affecting its design, were studies on the seasonal and annual variability in physical and planktonic features of the ETP, focusing on the role of ENSO in driving interannual variability of the system (Fiedler 1992, Fiedier et al. 1992, Murray et al. 1994). Specifically, we looked at associations at the coarse scale ( 1 to $100 \mathrm{~km}$; Hunt \& Schneider 1987), which included such variables as SST, SSS and thermocline characteristics, and those at the large scale, e.g. features of currents and water masses, whether or not the seabirds were in flocks. We were interested in whether seabird-environmental variable associations at the coarse scale could be used to infer associations at the large scale. This has not been done in any system. In addition, we investigated the consistency of any relationships between years, focusing on differences during the ENSO/LNSO events. In this paper, we focused on 1 portion of the ETP and examined the stability of seabird species-environmental relationships through repeated samples over time during spring and autumn. This type of sampling, though still observational in nature, is different from our previous work (Ribic \& Ainley 1988/89) where we had no repetition in either space or time. We collected our data as part of the larger EPOCS-TOGA project and did not have control over the exact cruise track. Nevertheless the census of seabirds along a consistent cruise track, in consistent seasons, over a long time period, covering 2 to 3 water masses and 2 current systems, provided an uncommon research opportunity.

\section{MATERIALS AND METHODS}

Study area. Cruises were conducted every spring and autumn, defined from a boreal perspective, for $8 \mathrm{yr}, 1984$ to 1991 . The study area in the ETP, between $10^{\circ} \mathrm{N}$ and $10^{\circ} \mathrm{S}$ and between $140^{\circ}$ and $90^{\circ} \mathrm{W}$ (Fig. 1), included 3 water masses and 2 current systems (Table 1). The characteristics of the surface water masses are determined by climate regimes at local and remote points of origin (Fiedler 1992). Tropical Surface Water is the warmest and least saline water in the ETP; SSS is low because rainfall exceeds evaporation beneath the cloudy and rainy intertropical convergence zone (Longhurst \& Pauly 1987). Cool, high-salinity southern Subtropical Surface Water is found in the central gyre of the South Pacific. Evaporation greatly exceeds rainfall and SSS exceeds $36 \mathrm{ppt}$ in the gyre center (Longhurst \& Pauly 1987). Equatorial Surface Water is found between the Tropical and southern Subtropical Surface Water masses; it appears as a

Table 1. Surface water masses and currents found in the study area (based on Wyrtki 1967, Longhurst \& Pauly 1987). Abbreviations used in other tables and in the text are given in parentheses

\begin{tabular}{|lccccc|}
\hline \multirow{2}{*}{ Surface water mass } & \multicolumn{2}{c}{ Latitudinal boundaries } & \multicolumn{2}{c|}{ Physical boundaries } & Current \\
& North & South & SST $\left({ }^{\circ} \mathrm{C}\right.$ ) & SSS (ppt) & \\
\hline Tropical (TSW) & $10^{\circ} \mathrm{N}$ & $-4^{\circ} \mathrm{N}$ & $25-28$ & $33-34$ & Equatorial Counter Current (ECC) \\
Equatorial (ESW) & $-4^{\circ} \mathrm{N}$ & $-0^{\circ}$ & $20-28$ & $34-35$ & South Equatorial Current (SEC) \\
Subtropical (SSW) & $\sim 0^{\circ}$ & $10^{\circ} \mathrm{S}$ & $19-28$ & $35-36.5$ & South Equatorial Current (SEC) \\
\hline
\end{tabular}


tongue of anomalously cold water extending westward along the Equator from the Peruvian coast (Fiedler 1992). SSS of the Equatorial Surface Water is intermediate between that of the low-salinity Tropical Surface Water and high-salinity Subtropical Surface Water (Table 1). The boundaries between the surface water masses are subject to seasonal fluctuations and are considered to be boundary zones rather than fronts (Wyrtki 1967). The Equatorial and Subtropical Surface Water masses are subsets of the South Equatorial Current (Fiedler 1992). At its northern boundary, the South Equatorial Current has the shallowest thermocline with moderate stratification; farther to the south the thermocline deepens. In contrast, the Equatorial Countercurrent has a medium depth thermocline with sharp stratification. Both currents are strongest in autumn.

Data collection. Spring cruises occurred between April and June (1988 cruise extended into the first week of July) and were within the study area, on average, $25 \mathrm{~d}$ (range: 17 to $35 \mathrm{~d}$ ). Autumn cruises occurred from October to early December (1985 cruise started in the last week of September) and were within the study area, on average, $23 \mathrm{~d}$ (range: 12 to $32 \mathrm{~d}$ ). Cruises made during ENSO were those in 1986 (autumn), 1987 (spring/autumn), and 1991 (spring/autumn). The 1988 spring and autumn cruises were made during a 'La Nin̄a' or cold-water event (LNSO).

Strip transects of 500 to $600 \mathrm{~m}$ width (depending on the height of the platform) were conducted from a height of 12 to $15 \mathrm{~m}$ using the method described by Ainley \& Boekelheide (1983), with adjustments for effect of bird movement relative to that of the ship (Spear et al. 1992; flight speeds from Spear \& Ainley 1997). Continuous counts were conducted during daylight hours whenever the ship was under way, weather permitting. Rarely did weather present any problems. Common and Latin names of the seabird species are given in Appendix 1. A total of 311,630, 1354, 941, 807 , 1938,2096 , and 4000 individuals were sighted in the study area on the 1984 to 1991 spring cruises, respectively. A total of $331,793,1946,815,1061,2487,2639$, and 759 individuals were sighted on the 1984 to 1991 autumn cruises, respectively.
For the coarse-scale species/habitat analysis, we divided the continuous counts into half-hour transects to coincide with the collection of environmental variables (see below). The numbers of half-hour transects made on the spring cruises 1984 to 1991, respectively, were $160,182,256,228,250,354,290$, and 492; and lengths averaged $11.9,12.9,12.4,13.3,13.7,12.8,12.7$, and $13.5 \mathrm{~km}$. The numbers of half-hour transects made on the autumn cruises 1984 to 1991 , respectively, were $97,190,259,184,234,313,389$, and 175, with lengths averaging $13.0,13.4,13.2,12.3,13.8,13.4,12.5$, and $13.6 \mathrm{~km}$. Examples of density estimates, typically low (less than 1 bird $\mathrm{km}^{-2}$ ), for the species we focus on are presented in Appendices 2 \& 3 .

We measured several physical factors at half-hour intervals for the coarse-scale species-environmental relationship analysis. These were SST $\left({ }^{\circ} \mathrm{C}\right)$, SSS (ppt), wind speed $\left(\mathrm{km} \mathrm{h}^{-1}\right)$, and swell height (to the nearest $0.3 \mathrm{~m}$ ). SST was measured directly using a thermometer SSS was measured by using a salinometer on bot- 
tled surface water samples. Wind speed and swell height were available from the ships' logs. In the coarse-scale analysis, we also included thermocline depth (TD; $\mathrm{m}$ ) and thermocline gradient ( $\mathrm{TG}$; definition given below). These variables were interpolated from XBTs deployed 4 to 6 times daily, approximately $85 \mathrm{~km}$ apart. TD was determined using the shallowest inflection point as determined by XBT printouts plotting temperature as a function of depth. Exceptions occurred when there was no inflection point, in which case the thermocline was at the ocean surface, or the XBT profiles showed more than 1 inflection. In the latter case, we assumed that the thermocline began at the depth of the strongest inflection. We measured TG as the temperature difference (nearest $0.1^{\circ} \mathrm{C}$ ) between the thermocline to a point $20 \mathrm{~m}$ below. TD and TG for each half-hour transect were the average values from the XBT casts bracketing the half-hour transects weighted by distance to the cast.

Data analysis. For the coarse-scale species-environmental variable analysis, we split the half-hour transects into 2 data sets using alternating transects. The 2 data sets consisted of non-continuous half-hour transects an average of 12 to $14 \mathrm{~km}$ apart, as a function of ship speed, which allowed us to compare consistency of the results from the parallel analyses. Unless noted otherwise, data from all years were used in the analyses. Only data on seabird species seen on more than 10 transects were analyzed.

We graphed species densities against environmental variables and identified that the relationships were neither linear nor monotonic. Because of the nonlinear, nonmonotonic relationships, we analyzed the speciesenvironment relationships within a season by year, using canonical correspondence analysis (CCA), a direct gradient analysis technique (ter Braak \& Prentice 1988, Palmer 1993, McCormick 1994). An alternative technique was canonical correlation analysis with polynomial terms (Gittins 1985). However, a previous comparison of the 2 methods yielded similar results (see Ainley et al. 1994). Therefore, we present only the CCA. To lessen the effect of the abundant species on the analysis, we analyzed the data using the transformed species variables, In(density +1 ) (ter Braak 1990). The analysis is done on standardized environmental variables so the environmental axes (e.g. cool to warm SST; shallow to steep TG) are interpreted in terms of relative relationships, facilitating comparisons between years. We identified a variable as an important component of the environmental axis if the percentage variance explained (as measured by intraset and interset correlations) exceeded $25 \%$. This cut off point had been used in earlier analyses (Ainley et al. 1994). Though there is no absolute lower bound for considering variables to be significant, using a vari- ance explained of greater than $25 \%$ requires that the environmental variables have a correlation greater than 0.5 with either the species axis or the environmental axis (ter Braak 1988)

We used polynomial regression to predict the values of SST and SSS at which the higher species densities occurred; these values are called the optima by Jongmann et al. (1987). In our case, we fitted a Gaussian curve using polynomial regression (Abrams 1985. Jongmann et al. 1987) and generalized linear models (McCullagh \& Nelder 1989, Numerical Algorithms Group 1987). We used the coefficients of the polynomial regression equation to predict the optima of SST and SSS for the different species. An optimum is predicted by $\left(-b_{1} / 2 b_{2}\right)$ where $b_{1}$ and $b_{2}$ are the parameter estimates from the regression: $\log ($ density +1$)=b_{0}+$ $b_{1} x+b_{2} x^{2}$. The variable $x$ is SST or SSS. Details are in Jongmann et al. (1987) and ter Braak \& Prentice (1988). We used these optima to predict water mass associations of each species (Table 1; Longhurst \& Pauly 1987) then compared results with the actual pattern found, as explained next.

To determine the relationships of species to the larger scale features of current and water mass, we focused on the sightings of individuals in relation to currents and water masses for each year (Haney \& Solow 1992). For the water mass analysis, the areas surveyed could be put into 1 of 3 water masses on the basis of SST and SSS characteristics (Table 1; Longhurst \& Pauly 1987). We separately categorized the surveyed areas into 1 of 2 current systems on the basis of marked changes in TD and TG (Longhurst \& Pauly 1987). The boundaries between currents could be distinguished during each cruise by a relatively rapid change in TD and/or stratification when the ship traveled from one current system to another. We used those cruises in. which greater than $100 \mathrm{~km}^{2}$ of ocean area was surveyed in a given water mass or current. During spring, in the water mass analysis, 4 cruises fit that criterion: 1987, 1988, 1990, and 1991; the current analysis included years 1985 to 1991. During autumn, 6 cruises were used for both analyses: 1986 through 1991

Within each water mass or current system, we summed the number of individuals seen per species to form a species-by-water-mass or species-by-current table of counts. To adjust for effort, we used the procedure of Haney (1986) and proportionately reduced the number of birds seen in the water masses or currents by the smallest amount of area surveyed. For example, in spring $1987,524.3 \mathrm{~km}^{2}$ of the Tropical Surface Water mass was sampled, $615.9 \mathrm{~km}^{2}$ for the Equatorial Surface Water mass, and $673.6 \mathrm{~km}^{2}$ for the Subtropical Surface Water mass. Thus all counts in the Equatorial Surface Water mass were multiplied by 524.3/615.9 and all counts in the Subtropical Surface Water mass 
were multiplied by 524.3/673.6. All fractions were rounded to the nearest integer. We only used species in the current analyses with more than 15 individuals seen (after adjustment for effort) and, for the water mass analysis, we only used species with more than 25 individuals seen (after adjustment for effort). In general, $69.8 \%$ of the species included in any 1 analysis had more than 50 individuals seen (after adjustment for effort) for the current analyses. In general, $52.1 \%$ of the species included in any 1 analysis had more than 60 individuals seen (after adjustment for effort) for the water mass analyses. Statistically, we asked whether species were seen more often in a certain water mass or current system rather than being found uniformly throughout the study area. Using SPSS/PC+ (Norusis 1988), we analyzed the data using $\chi^{2}$ tests and residual analysis (Fienberg 1980), with an alpha of 0.05 as the cutoff for significance. We summarized the results of the species associations by water mass and current in tabular format. We present graphs of the proportion of individuals occurring in the different water masses and current systems by cruise for the species seen on 4 or more cruises to illustrate the results from the analyses.

Because flocks of some species were sighted (see 'Results'), we checked the test for the effect of aggregation; otherwise we might have rejected the null hypothesis too often (Garson \& Moser 1995). We reanalyzed the tables using a weighted $\chi^{2}$ test described by Garson \& Moser (1995) as follows. The continuous counts within a day were aggregated into larger spatial units based on which water mass or current the counts were occurring in. We considered each of the larger spatial units to be 1 sample of the water mass or current (Haney \& Solow 1992). We used larger spatial units that were similar in area (this is one way to control for equal sampling effort). On average, depending on the cruise, for the water mass analysis, the large spatial units were 133 to $168 \mathrm{~km}$ in length, and for the current analysis, were 181 to $256 \mathrm{~km}$ in length. Number of samples per water mass or current ranged from 2 to 9 , depending on the cruise. Garson \& Moser (1995) adjust the overall $\chi^{2}$ statistic (i.e. the test statistic calculated from the species-by-water-mass or species-bycurrent tables) for both effort (number of samples per water mass or current) and aggregation (effect of flocks) using a weight per water mass or current based on the number of samples per water mass or current and a $\chi^{2}$ statistic based on the samples within each water mass or current. This weight, in essence, is an estimate of the variance of the samples within the water mass or current and describes how similar the samples are to each other. If flocks are only seen on a few of the samples, then the number of individuals per species will be high on a few of the samples and low on the other samples and the $\chi^{2}$ statistic of these samples will be large (the samples are not similar to one another). The more dissimilar the samples are, the more the overall $\chi^{2}$ statistic is reduced. Equations and details are in Garson \& Moser (1995). The adjusted $\chi^{2}$ statistics were significant $(p<0.05)$, verifying the first analysis based on Haney (1986). An alternative check would be to use a randomization test on the sightings (Manly 1991) with an adjustment for equal effort.

\section{RESULTS}

\section{Observations of flocks}

Relatively few seabirds were seen in flocks, defined according to the criterion of $\mathrm{Au} \&$ Pitman (1988): a group of 10 or more seabirds. In spring 1984 to 1991, flock density (number of flocks $\mathrm{km}^{-2}$ ) in the Equatorial and Subtropical Surface Water masses, where all the flocks were sighted, was as follows: 0, 0.003, 0.002, $0.006,0.0005,0.002,0.004$, and 0.013 , respectively. In autumn 1984 to 1991, flock density, again restricted to the Equatorial and Subtropical Surface Water masses, was: $0.001,0.0006,0.004,0.002,0.002,0.007,0.004$, and 0.012 , respectively. We also checked to see which species occurred in the flocks (Ballance 1993). In both seasons, sooty tern, wedge-tailed shearwater, and Juan Fernandez petrel made up the majority of the species in the flocks. Sooty terns made up an average of $80.6 \%$ of the flocks in which the species was seen in the spring ( $\mathrm{SE}=2.6 \%, \mathrm{n}=64$ flocks) and $67.8 \%$ in the autumn ( $\mathrm{SE}=4.2 \%, \mathrm{n}=47$ flocks). Wedge-tailed shearwaters made up an average of $27.5 \%$ of the flocks in which that species was present in the spring ( $\mathrm{SE}=4.6 \%, \mathrm{n}=41$ flocks) and $29.3 \%$ in the autumn ( $\mathrm{SE}=5.3 \%, \mathrm{n}=28$ flocks). Juan Fernandez petrel were not seen in flocks often in the spring (mean \% composition $=7.0 \%, \mathrm{SE}=1.2 \%, \mathrm{n}=16$ flocks) but were a more common component in the autumn (mean \% composition $=23.9 \%, \mathrm{SE}=3.5 \%, \mathrm{n}=32$ flocks).

\section{Seabird-environmental relationships}

\section{Spring}

Focusing on the coarse-scale species-environmental variable relationships first, regardless of whether the cruise occurred during ENSO/LNSO events or not, SST was a major component of the first or second environmental axis [7/8 yr (i.e. 7 of 8 years)] (Table 2). Other important components were SSS (6/8 yr) and swell height $(5 / 8 \mathrm{yr})$. TD or TG, when they were important components of the first canonical axis, were generally paired with SST (Table 2). A little over half 
Table 2. Summary of canonical correspondence analysis for spring 1984 to 1991 in the eastern tropical Pacific. Important envlronmental vanables are those having more than $25 \%$ of their variances associated with the environmental axis (based on intraset and interset correlations). The numbers separated by / are the results of the split data sets analyzed separately

\begin{tabular}{|c|c|c|c|c|c|c|}
\hline \multirow[t]{2}{*}{ Year } & \multicolumn{3}{|c|}{ First species-environmental variable axis } & \multicolumn{3}{|c|}{ Second species-environmental variable axis } \\
\hline & Correlation & $\begin{array}{l}\% \text { variance } \\
\text { explaıned }\end{array}$ & $\begin{array}{c}\text { Important environ- } \\
\text { mental variables }\end{array}$ & Correlation & $\begin{array}{l}\% \text { variance } \\
\text { explained }\end{array}$ & $\begin{array}{l}\text { Important environ- } \\
\text { mental variables }\end{array}$ \\
\hline 1984 & $0.68 / 0.57$ & $66.0 / 60.6$ & Wind speed, swell height & & & \\
\hline 1985 & $0.71 / 0.72$ & $44.3 / 43.0$ & SST, ID, swell height & $0.51 / 0.58$ & $22.2 / 29.7$ & TG \\
\hline 1986 & $0.80 / 0.76$ & $51.2 / 44.8$ & TG, swell height & $0.67 / 0.69$ & $30.7 / 32.9$ & SSS, SST \\
\hline 1987 & $0.80 / 0.79$ & $58.8 / 56.9$ & SST, TD, SSS & $0.67 / 0.70$ & $28.3 / 28.2$ & Wind speed \\
\hline 1988 & $0.80 / 0.79$ & $54.9 / 57.3$ & SST, SSS & $0.58 / 0.56$ & $27.7 / 24.2$ & Swell height \\
\hline 1989 & $0.91 / 0.92$ & $55.0 / 53.9$ & SST, TD & $0.72 / 0.73$ & $29.7 / 30.5$ & SSS \\
\hline 1990 & $0.80 / 0.77$ & $42.1 / 39.0$ & SST, SSS, swell height & $0.72 / 0.78$ & $29.0 / 33.0$ & TD \\
\hline 1991 & $0.79 / 0.79$ & $61.5 / 54.9$ & SSS, TG & $0.56 / 0.48$ & $20.7 / 16.0$ & SST \\
\hline
\end{tabular}

of the variability in the species-environmental variable relationship was explained by the first axis (first data set: $54 \%$ mean variance explained; second set: $51.3 \%$ ), while a little more than a quarter of the variability was explained by the second axis (first set: $26.9 \%$ mean variance explained, second set: $27.8 \%$ ) (Table 2).

Focusing on species seen in at least 5 years and their placements along the environmental axes (Fig. 2), we found the following patterns during the non-ENSO/ LNSO years. Leach's storm-petrel occurred at relatively cooler SST (4/5 yr) with lower SSS (3/4 yr) and higher swells $(3 / 5 \mathrm{yr})$. In contrast, wedge-rumped storm-petrel was seen at higher SSS (3/4 yr) and lower swell heights $(4 / 4 \mathrm{yr}$ ) with variable SST (cooler water 2/4 yr; warmer waters: $2 / 4$ yr). Juan Fernandez petrel was seen at lower SSS (4/4 yr) and lower swell heights ( $3 / 4 \mathrm{yr}$ ) with variable SST (cooler waters: 2/4 yri warmer waters: $2 / 4$ yr). Wedge-tailed shearwater (SHWT) and sooty tern (TESO) were generally seen at the end of the canonical environmental axis opposite from Leach's storm-petrel, i.e. over relatively warmer SST (SHWT $4 / 5 \mathrm{yr}$; TESO: $2 / 3 \mathrm{yr}$ ) with higher SSS (SHWT: $3 / 5$ yr; TESO: $3 / 3 \mathrm{yr}$ ). These species were also seen in waters with higher swells (SHWT: $4 / 5 \mathrm{yr}$; TESO: 2/3 yr). White-winged petrel (PTLE) and blackwinged petrel (PTBW) differed from the other species by being found at relatively cool SST (PTLE: $3 / 3 \mathrm{yr}$; PTBW: 2/3 yr) with higher SSS (PTLE: 2/3 yr; PTBW: $3 / 3 \mathrm{yr}$ ). These species were also seen in waters with higher swells (PTLE: 2/3 yr; PTBW: 2/3 yr). Mean envi- ronmental values for the transects where the species were seen are presented in Appendix 2.

During ENSO/LNSO events, the SST and SSS patterns presented above stayed the same for Leach's storm-petrel [cooler SST (2/3 yr) with lower SSS (2/3 yr)], white-winged petrel [cooler SST ( $3 / 3 \mathrm{yr})$ with higher SSS $(3 / 3$ yr)], black-winged petrel [cooler SST $(2 / 3$ yr) with higher SSS $(3 / 3 \mathrm{yr})]$, and wedge-tailed shearwater [warmer SST ( $2 / 3$ yr) with higher SSS $(2 / 3$ yr $)]$. The pattern with wedge-rumped storm-petrel changed and became the same as Leach's storm-petrel [cooler SST ( $2 / 3 \mathrm{yr})$ with lower SSS $(2 / 3 \mathrm{yr})]$. The pattern for Juan Fernandez petrel also changed from association with waters of lower SSS and variable SST to an association with waters of higher SSS (2/3 yr) and cooler SST ( $3 / 3 \mathrm{yr})$. Finally, sooty tern stayed associated with waters of higher SSS (2/2 yr) but there was no consistent association with warmer SST ( $1 / 2 \mathrm{yr})$

Focusing on large-scale features, individual species within a year were seen significantly more often in specific current systems (all $\chi^{2}$ had $p<0.001$; Table 3 ). Focusing on the non-ENSO/LNSO years, wedge-rumped storm-petrel ( $3 / 3$ yr), black-winged petrel ( $2 / 3$ yr), whitewinged petrel $(2 / 3 \mathrm{yr})$, and sooty tern $(3 / 3 \mathrm{yr})$ were seen more often in the South Equatorial Current (Fig 3). Mean percentage occurrence of wedge-runiped stormpetrels in the South Equatorial Current was $88.9 \%$ ( $\mathrm{SE}=$ $11.1 \%, \mathrm{n}=3 \mathrm{yr}$ ), $77.4 \%$ for black-winged petrels ( $\mathrm{SE}=$ $8.8 \%, \mathrm{n}=3 \mathrm{yr}$ ), $88.9 \%$ for white-winged petrels ( $\mathrm{SE}=$ $11.1 \%, \mathrm{n}=3 \mathrm{yr}$ ) and $70.5 \%$ for sooty tern (SE $=11.9 \%, \mathrm{n}$ $=3$ yr). Juan Fernandez petrel was seen more often than

Fig. 2. Biplots from canonical correspondence analysis for spring (a) 1984, (b) 1985, (c) 1986, (d) 1987, (e) 1988, (f) 1989, (g) 1990, and (h) 1991. All variables are standardized to have zero mean and unit variance; therefore, axes are in standard deviation units. Scores for the environmental variables are presented as arrows, the length of which indicates the importance of the variable to the habitat axis. Species scores (represented by the 4 -letter codes) are measures of the centers of the species distribution along the environmental axis. Species codes are in Appendix 1 
(a)

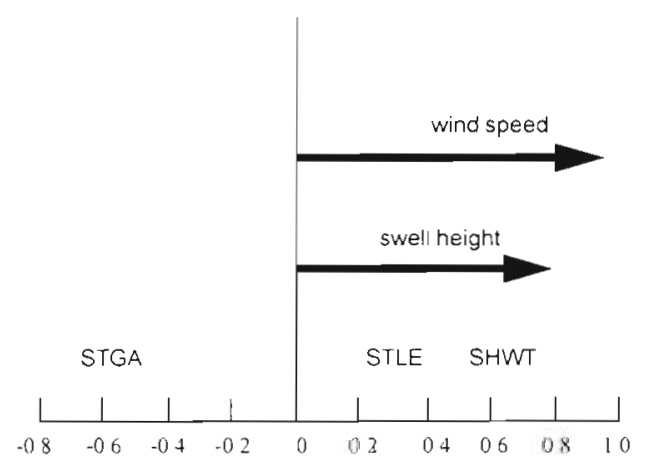

(c)

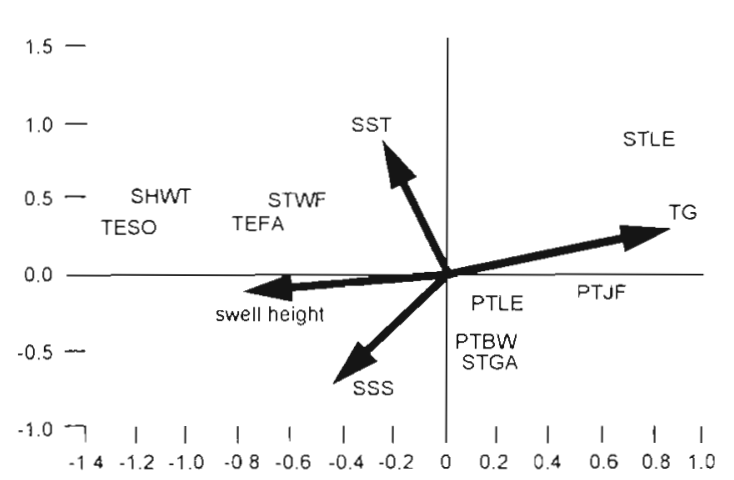

(e)

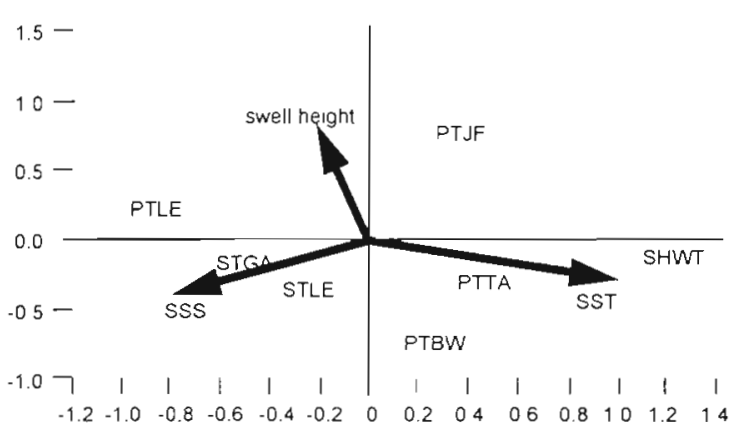

(g)

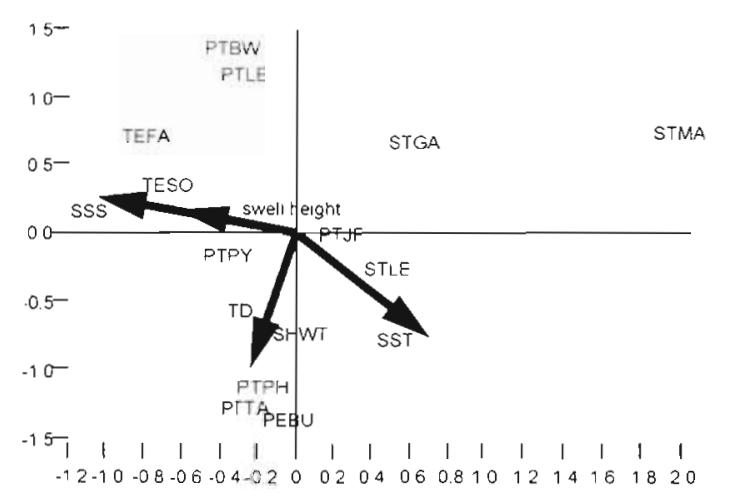

(b)

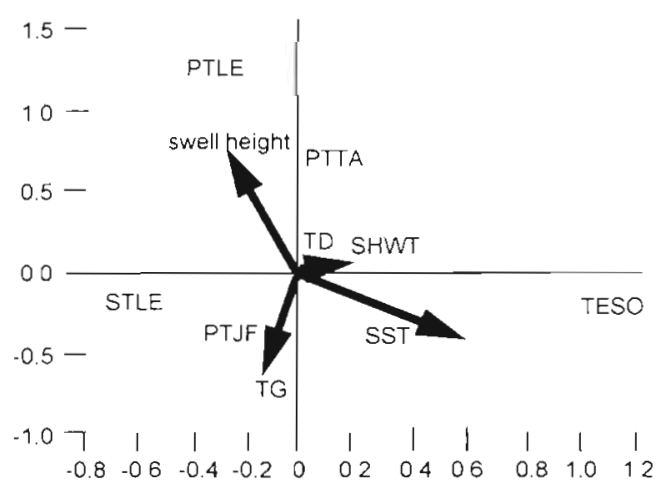

(d)

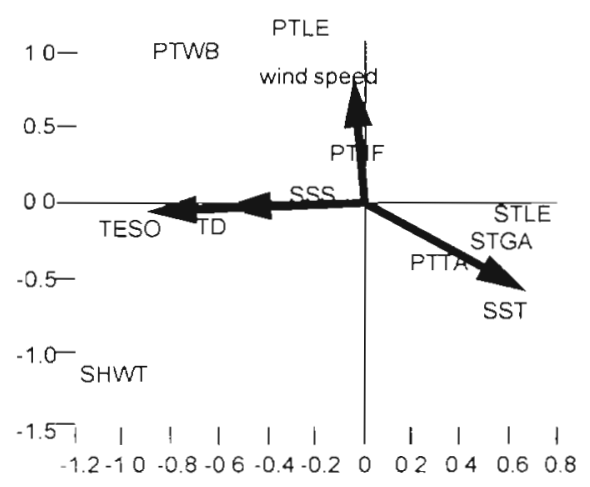

(f)

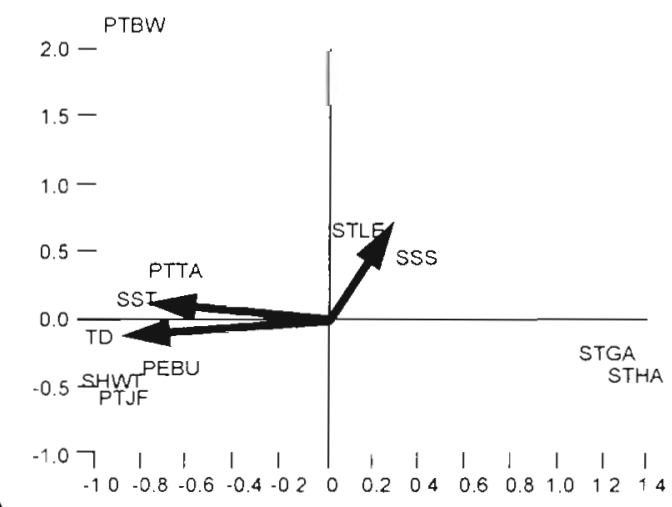

(h)

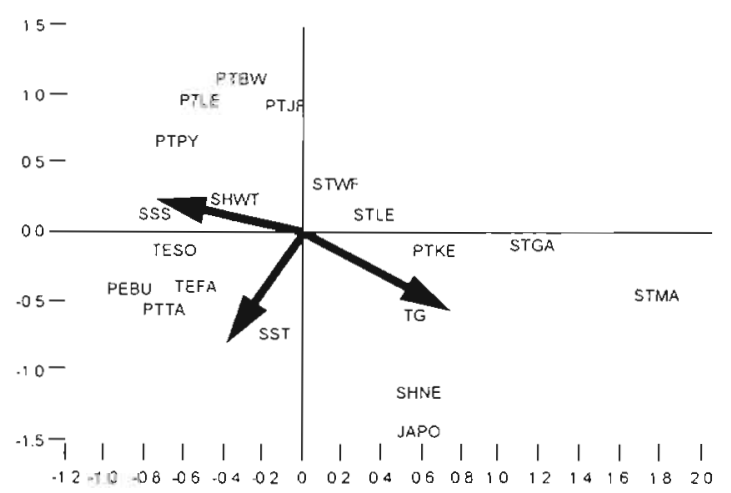


(a)

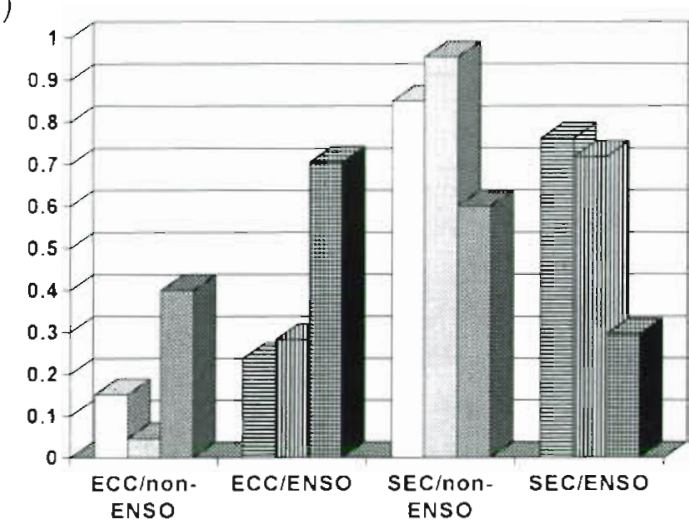

(c)

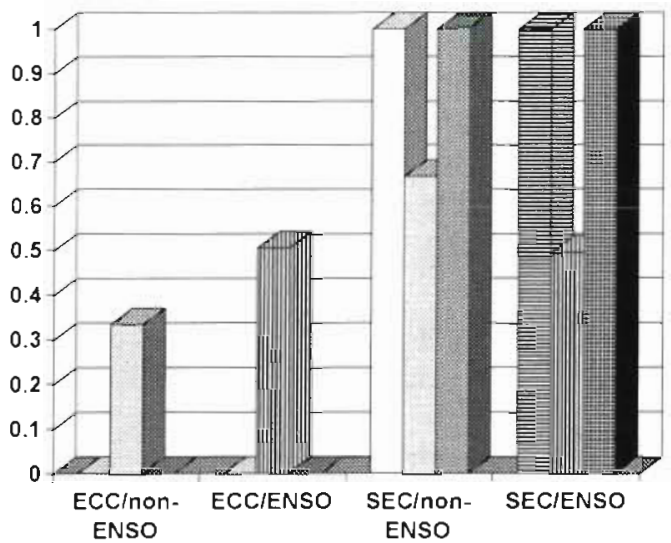

(e)

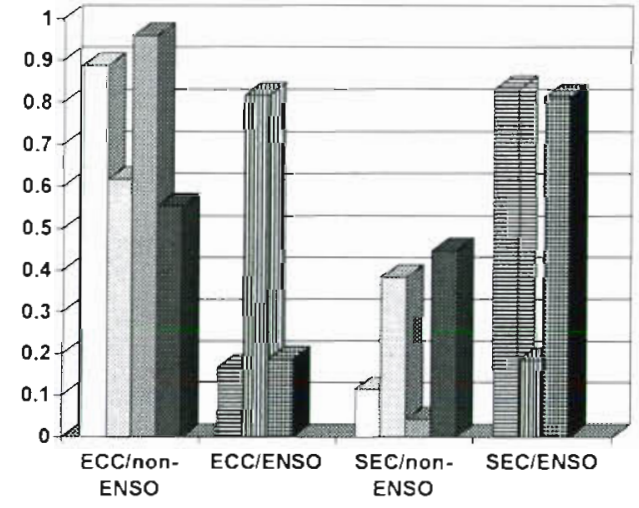

(g)

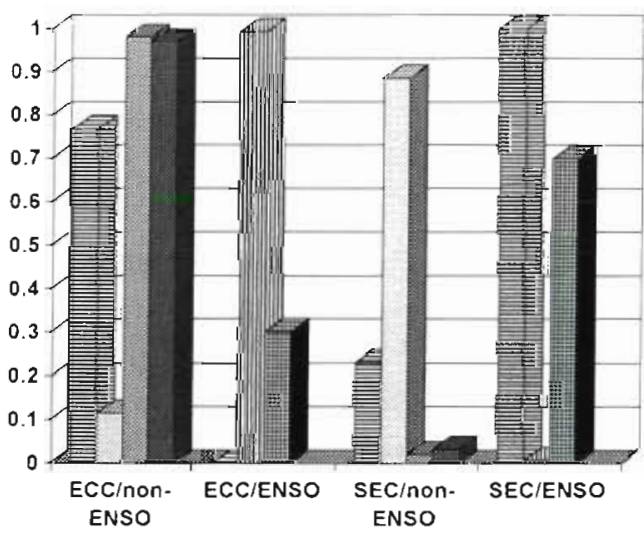

(b)

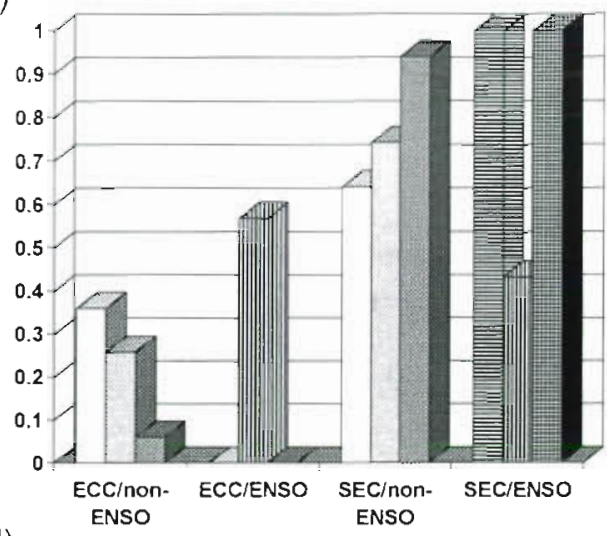

(d)

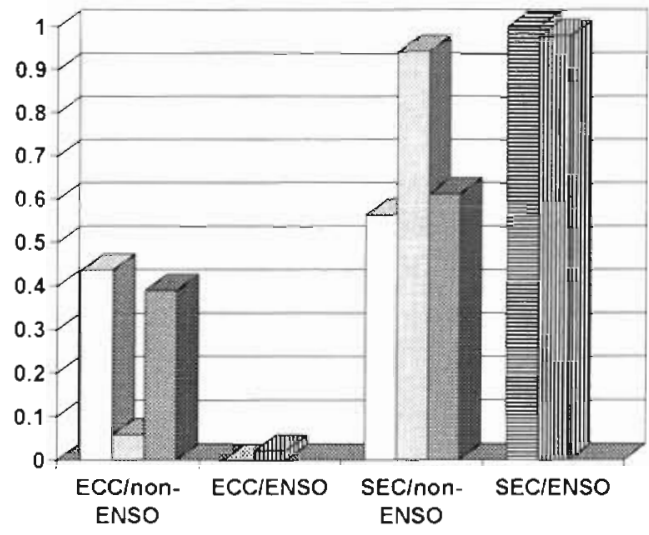

(f)

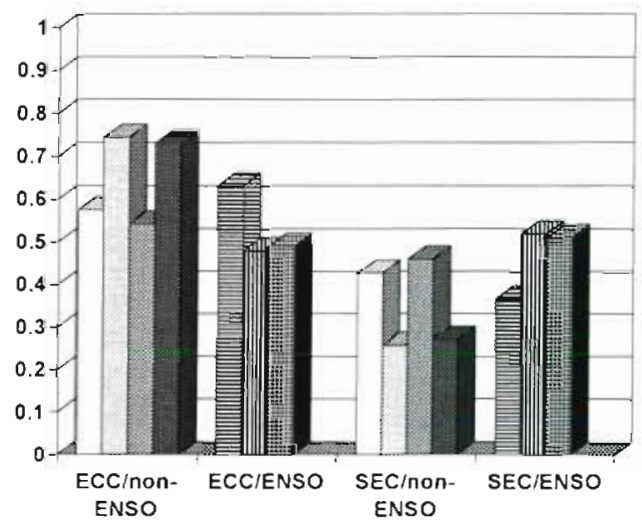

Fig. 3. Proportion of occurrence by current system and by nonENSO/LNSO and ENSO/LNSO years for 7 species seen on the spring cruises: (a) wedge-rumped storm-petrel, (b) black-winged petrel, (c) white-winged petrel, (d) sooty tern, (e) Juan Fernandez petrel, (f) Leach's storm-petrel, and (g) wedge-tailed shearwater. The $y$-axis is proportion of individuals of the species that fell into the Equatorial Countercurrent (ECC) or the Southern Equatorial Current (SEC). The 'nonENSO' designation on the $x$-axis indicates the data are from the cruises where neither an ENSO nor an LNSO occurred. The 'ENSO' designation on the $x$-axis indicates that the data are from the crujses that occurred during an ENSO or LNSO. The different shadings indicate different cruises within a category. The shadings for the ECC/non-ENSO and SEC/nonENSO categories correspond (e.g. the white bar is the same cruise for those 2 categories). The shadings for the ECC/ENSO and SEC/ENSO categories also correspond (e.g. the same shaded bar is the same cruise for the 2 categories) 
Table 3. Current and water mass associations for seabird species seen in the equatorial Pacific in the spring. Water mass and current abbreviations are in Table 1. None: no specific water mass or current system preferred. n: number of years used in analysis for the species. Numbers in parentheses are the water mass associations predicted by the SST and salinity optima from the coarse-scale analysis

\begin{tabular}{|c|c|c|c|c|c|c|c|c|c|}
\hline \multirow{2}{*}{ Species } & \multicolumn{4}{|c|}{ Current system association } & \multicolumn{5}{|c|}{ Water mass association } \\
\hline & $\mathrm{ECC}$ & SEC & None & $\mathrm{n}$ & TSW & ESW & SSW & None & $n$ \\
\hline Wedge-rumped storm-petrel & 1 & 3 & 2 & 6 & $2(2)$ & $0(1)$ & $2(1)$ & 0 & 4 \\
\hline Leach's storm-petrel & 4 & 3 & 0 & 7 & $2(2)$ & $1(1)$ & $1(1)$ & 0 & 4 \\
\hline Black-winged petrel & 0 & 5 & 1 & 6 & $0(0)$ & $2(2)$ & $2(2)$ & 0 & 4 \\
\hline White-winged petrel & 0 & 3 & 1 & 4 & $0(0)$ & $1(1)$ & $2(2)$ & 0 & 3 \\
\hline Juan Fernandez petrel & 4 & 1 & 2 & 7 & $1(0)$ & $2(3)$ & $1(1)$ & 0 & 4 \\
\hline Wedge-tailed shearwater & 3 & 2 & 2 & 7 & $0(0)$ & $3(4)$ & $1(0)$ & 0 & 4 \\
\hline Sooty tern & 0 & 5 & 0 & 5 & $0(0)$ & $2^{a}(1)$ & $3(2)$ & 0 & 3 \\
\hline
\end{tabular}

expected in the Equatorial Countercurrent $(3 / 4 \mathrm{yr})$ (mean $\%$ occurrence $=75.4 \%, \mathrm{SE}=9.9 \%, \mathrm{n}=4 \mathrm{yr})$ (Fig. 3). Leach's storm-petrel and wedge-tailed shearwater, however, were not consistently associated with a particular current system. Leach's storm-petrel (STLE) and wedge-tailed shearwater (SHWT) were seen in both the Equatorial Countercurrent (STLE: $2 / 4$ yr; SHWT: $2 / 4$ yr) and in the South Equatorial Current in (STLE: 2/4 yr; SHWT: $1 / 4$ yr) (Fig. 3).

During ENSO/LNSO events, sooty tern (mean occurrence $=98.9 \%, \mathrm{n}=2 \mathrm{yr}$ ), black-winged petrel (mean occurrence $=81.0 \%, \mathrm{SE}=18.9 \%, \mathrm{n}=3 \mathrm{yr}$ ), and whitewinged petrel (mean occurrence $=83.1 \%, \mathrm{SE}=16.8 \%$, $\mathrm{n}=3 \mathrm{yr}$ ) remained associated with the South Equatorial Current (Fig. 3). However, wedge-rumped storm-petrel was not associated consistently with any 1 current (ECC: 1/3 yr; SEC: $1 / 3$ yr) (Fig. 3). Juan Fernandez petrel (Fig. 3) was associated with the South Equatorial Current $(2 / 3$ yr) (mean \% occurrence for those 2 years $=82.3 \%)$ rather than the Equatorial Countercurrent (1/3 yr) (occurrence $=18.3 \%$ ). Leach's storm-petrel (Fig. 3) was associated with the Equatorial Countercurrent (2/3 yr) (mean \% occurrence $=53.4 \%, \mathrm{SE}=16.9 \%, \mathrm{n}=3 \mathrm{yr}$ ), while wedge-tailed shearwater continued to have no clear association with currents (ECC: $1 / 3$ yr; SEC: 1/3 yr).

In the 4 years where the water masses were sampled enough for analysis, there was less consistency in species associations with specific water masses between years (all $\chi^{2}$ had $p<0.001$; Table 3) (Fig. 4). We note that 3 of the 4 years here were ENSO/LNSO years so we will not compare non-ENSO/LNSO and ENSO/ LNSO results. However, the predicted water mass associations made using the SST and SSS optima for individual species were consistent with the observed pattern (Table 3). In addition, the water mass associa tions tended to be consistent with the related current system to which the species was associated (see definitions in Table 1). For example, the species associated with the South Equatorial Current were associated with the Equatorial Surface Water and/or the Subtropical Surface Water, both of which are subsets of the South Equatorial Current.

\section{Autumn}

Considering the coarse-scale species-environmental variable relationships, SST and TD were important environmental variables for the first canonical axis for all 8 years (Table 4 ); variance explained averaged $64.9 \%$ (set 1 ) and $63.7 \%$ (set 2). SSS was an important component of the second environmental axis on 3 of the 6 cruises where a second axis was important (Table 4); variance explained averaged $23.4 \%$ (set 1) and $27 \%$ (set 2 ).

Focusing on species seen in at least 5 years and their placements along the environmental axes (Fig. 5), we found the following patterns regardless of whether the cruises occurred during an ENSO/LNSO event or not. Leach's storm-petrel (STLE) and wedge-rumped storm-petrel (STGA) occurred at relatively cooler SST (7/8 yr) with shallower TD (8/8). The 2 species also occurred in waters with lower SSS (STLE: $7 / 8 \mathrm{yr}$; STGA: 6/8 yr). Juan Fernandez petrel (PTJF), blackwinged petrel (PTBW) and sooty tern (TESO) were consistently found in warmer waters with deeper TD (PTJF: $8 / 8$ yr; PTBW: $5 / 5$ yr; TESO: $5 / 5$ yr). These species also tended to be found in waters with higher SSS (PTJF: 5/8; PTBW: $3 / 5$ yr ; TESO: $5 / 5$ yr). White-winged petrel also was seen in waters with deeper TD ( $7 / 8$ yr) and higher SSS (8/8 yr) but was not consistently seen in warmer waters ( $4 / 8 \mathrm{yr}$ ). Mean environmental values for the transects where the species were seen are presented in Appendix 3.

Most of the species were consistently associated with specific current systems (all $\chi^{2}$ had $p<0.001$; Table 5). 
(a)

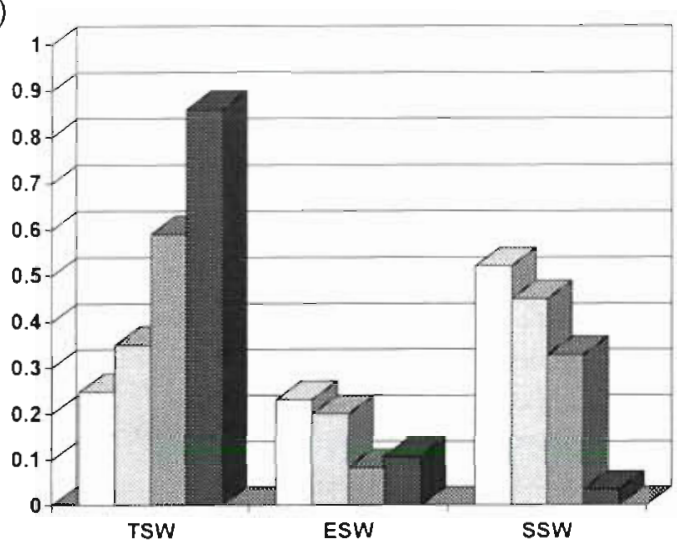

(c)

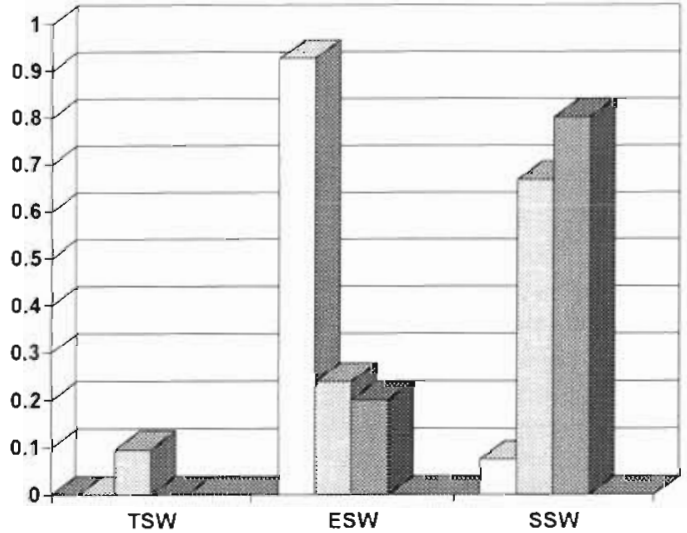

(e)

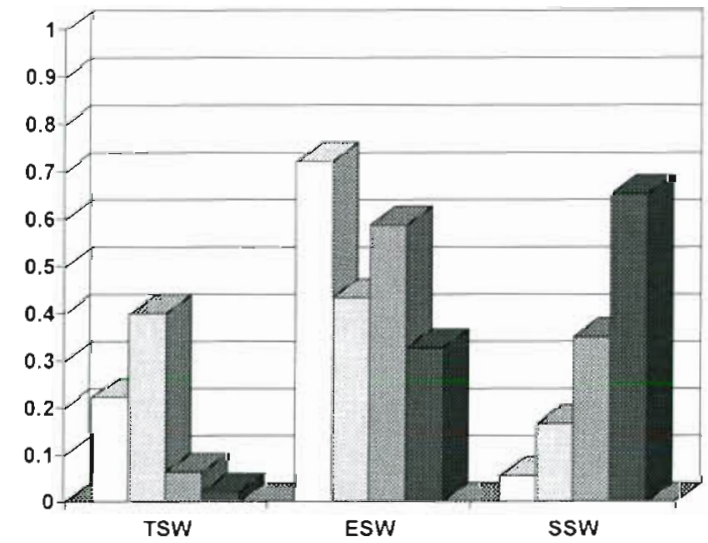

(g)

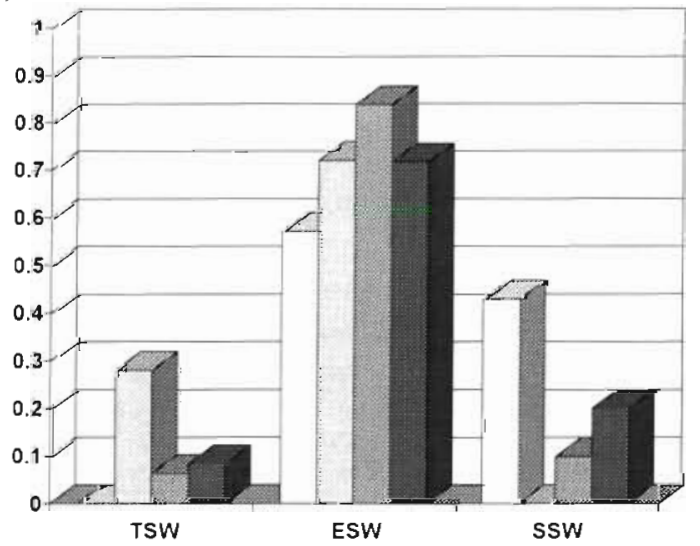

(b)

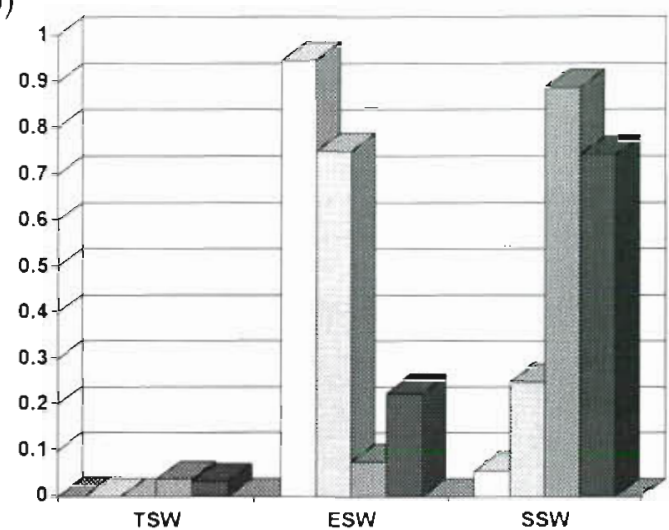

(d)

(f)
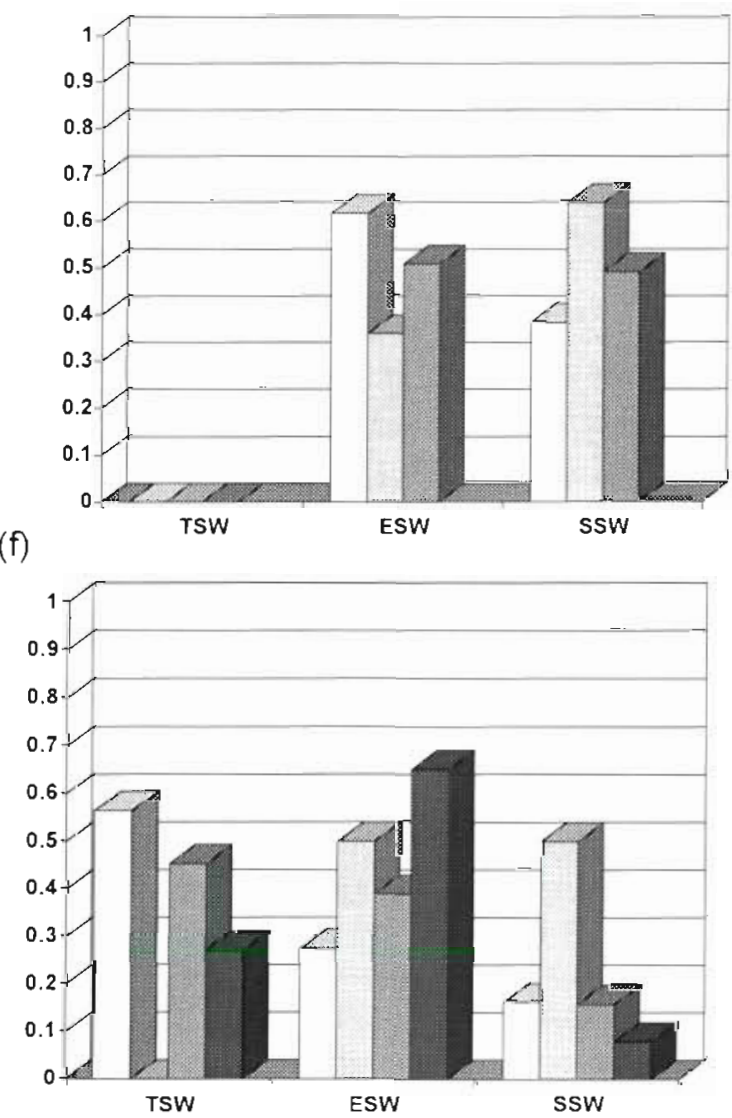

Fig. 4. Proportion of occurrence by water mass for 7 species seen on the spring cruises: (a) wedge-rumped storm-petrel, (b) blackwinged petrel, (c) white-winged petrel, (d) sooty tern, (e) Juan Fernandez petrel, (f) Leach's storm-petrel, and (g) wedge-tailed shearwater. The $y$-axis is proportion of individuals of the species that fell into the Tropical Surface Water mass (TSW), the Equatorial Surface Water mass (ESW), and the Subtropical Surface Water mass (SSW). The shadings for the water masses correspond (e.g. the white bar is the same cruise for the 3 water masses) 
Table 4. Summary of canonical correspondence analysis for autumn 1984 to 1991 in the eastern tropical Pacific. Important environmental variables are those having greater than $25 \%$ of their variances associated with the environmental axis (based on intraset and interset correlations). The numbers separated by / are the results of the split data sets analyzed separately

\begin{tabular}{|c|c|c|c|c|c|c|}
\hline \multirow[t]{2}{*}{ Yeàr } & \multicolumn{3}{|c|}{ First species-environmental variable axis } & \multicolumn{3}{|c|}{ Second species-environmental variable axis } \\
\hline & Correlation & $\begin{array}{l}\% \text { variance } \\
\text { explained }\end{array}$ & $\begin{array}{l}\text { Important environ- } \\
\text { mental variables }\end{array}$ & Correlation & $\begin{array}{l}\% \text { variance } \\
\text { explained }\end{array}$ & $\begin{array}{c}\text { Important environ- } \\
\text { mental variables }\end{array}$ \\
\hline 1984 & $0.73 / 0.71$ & $82.5 / 74.3$ & SST, TD & & & \\
\hline 1985 & $0.86 / 0.90$ & $78.2 / 80.2$ & SST, TD & & & \\
\hline 1986 & $0.80 / 0.78$ & $64.5 / 67.8$ & SST, TD & $0.58 / 0.58$ & $22.3 / 18.2$ & TG \\
\hline 1987 & $0.75 / 0.77$ & $57.4 / 51.9$ & SST, TD & $0.51 / 0.56$ & $23.5 / 26.1$ & Wind speed, swell helght \\
\hline 1988 & $0.71 / 0.76$ & $57.7 / 62.0$ & SST, TD & $0.51 / 0.62$ & $18.3 / 28.7$ & SSS \\
\hline 1989 & $0.79 / 0.80$ & $67.4 / 68.5$ & SST, TD & $0.49 / 0.51$ & $15.7 / 16.0$ & SSS \\
\hline 1990 & $0.79 / 0.73$ & $57.1 / 50.7$ & SST, TD & $0.56 / 0.64$ & $32.1 / 40.1$ & SSS \\
\hline 1991 & $0.74 / 0.70$ & $54.3 / 54.1$ & TD, SSS & $0.61 / 0.57$ & $28.5 / 32.8$ & SST, swell height \\
\hline
\end{tabular}

Table 5. Current and water mass associations for seabird species seen in the equatorial Pacific in the autumn. Water mass and current abbreviations are in Table 1 . None: no specific water mass or current system preferred. n: number of years used in analysis for the species. Numbers in parentheses are the water mass associations predicted by the SST and salinity optima from the coarse-scale analysis

\begin{tabular}{|c|c|c|c|c|c|c|c|c|c|}
\hline \multirow[t]{2}{*}{ Species } & \multicolumn{4}{|c|}{ Current system association } & \multicolumn{5}{|c|}{ Water mass association } \\
\hline & ECC & $\mathrm{SEC}$ & None & $\mathrm{n}$ & TSW & ESW & SSW & None & $\mathrm{n}$ \\
\hline Wedge-rumped storm-petrel & 0 & 3 & 3 & 6 & $0(0)$ & $1(4)$ & $1(0)$ & 2 & 4 \\
\hline Leach's storm-petrel & 2 & 3 & 1 & 6 & $4(3)$ & $0(3)$ & $0(0)$ & 2 & 6 \\
\hline Juan Fernandez petrel & 4 & 1 & 1 & 6 & $1(1)$ & $3(5)$ & $2(0)$ & 0 & 6 \\
\hline Black-winged petrel & 3 & 0 & 0 & 3 & $1(1)$ & $1(1)$ & $0(0)$ & 0 & 2 \\
\hline White-winged petrel & 0 & 5 & 1 & 6 & $0(0)$ & $0(1)$ & $5(4)$ & 0 & 5 \\
\hline Wedge-tailed shearwater & 4 & 0 & 0 & 4 & $2(2)$ & $2^{d}(2)$ & $0(0)$ & 1 & 4 \\
\hline Sooty tern & 1 & 5 & 0 & 6 & $0(0)$ & $3^{6}(4)$ & $5(2)$ & 0 & 6 \\
\hline
\end{tabular}

Focusing on the non-ENSO/LNSO years, blackwinged petrel, Juan Fernandez petrel, and wedgetailed shearwater were seen more of ten in the Equatorial Countercurrent ( $2 / 2$ yr). Black-winged petrel had a mean percentage occurrence of $95.7 \%$ in the Equatorial Countercurrent for the 2 years, Juan Fernandez petrel averaged $89.4 \%$ occurrence, and wedge-tailed shear:ater averaged $95.1 \%$ occurrence. Sooty tern. white-winged petrel, wedge-rumped storm-petrel and Leach's storm-petrel were seen more often in the South Equatorial Current (2/2 yr) (Fig. 6). Sooty tern averaged $62.1 \%$ occurrence in the South Equatorial Current for the 2 years, white-winged petrel averaged $94.5 \%$ occurrence, wedge-rumped storm-petrel averaged $81.3 \%$ occurrence, and Leach's storm-petrel averaged $62.0 \%$ occurrence.

During the ENSO/LNSO events, wedge-tailed shearwater remained associated with the Equatorial Countercurrent $(2 / 2 \mathrm{yr})$ (mean occurrence for the 2 years $=82.6 \%$ ) black -winged petrel was associated with the Equatorial Countercurrent in the one ENSO cruise it was seen in large enough numbers to analyze
(Fig. 6). Juan Fernandez petrel, in contrast, was found associated with both currents (ECC: $2 / 4 \mathrm{yr}$; SEC: $1 / 4 \mathrm{yr}$ ) (Fig. 6). Both sooty tern (3/4 yr) and white-winged petrel (4/4 yr) remained associated with the South Equatorial Current (Fig. 6). Sooty tern had a mean occurrence of $86.6 \%(\mathrm{SE}=13.2 \%, \mathrm{n}=3)$ in the South Equatorial Current and white-winged petrel averaged $75.8 \%$ occurrence (SE $=10.7 \%, \mathrm{n}=4$ ) in that current. The storm-petrels differed from the associations in the non-ENSO/LNSO years; wedge-rumped storm-petrel had no association with either current system (3/4 yr) while Leach's storm-petrel was associated with both currents (ECC: 2/4 yr; SEC: 1/4 yr) (Fig. 6).

Within a year, species were seen significantly more often in specific water masses (all $\chi^{2}$ had $p<0.001$; Table 5) though the particular water mass varied annually (Fig. 7). Of the 3 species seen in both nonENSO/LNSO years and in at least 2 ENSO/LNSO events, the following comparisons can be made. Sooty tern (Fig. 7) was associated with Subtropical Surface Water regardless of the presence of ENSO/LNSO (non-ENSO/LNSO: 2/2 yr; ENSO/LNSO: 3/4 yr). Mean 
percentage occurrence for the species in the Subtropical Surface Water mass was $54.7 \%(\mathrm{SE}=7.0 \%, \mathrm{n}=6)$. However, in the ENSO/LNSO events, sooty tern was also associated with the Equatorial Surface Water mass $(3 / 4 \mathrm{yr}$ ) (mean percentage occurrence $=49.9 \%, \mathrm{SE}=$ $9.7 \%, \mathrm{n}=4$ ). Juan Fernandez petrel (Fig. 7) was associated with the Equatorial Surface Water mass during the non-ENSO/LNSO years (2/2 yr) (mean \% occurrence for the 2 years $=50.3 \%$ ) but had differing associations during the ENSO/LNSO events (TSW: 1/4 $\mathrm{yr}$; ESW: $1 / 4$ yr; SSW: $2 / 4$ yr). Leach's storm-petrel (Fig. 7), seen in association with the Tropical Surface Water mass once in the 2 non-ENSO/LNSO years, was associated with that water mass during the ENSO/LNSO events $(3 / 4 \mathrm{yr})$. Leach's storm-petrel had a mean \% occurrence in the Tropical Surface Water mass of $52.5 \%(\mathrm{SE}=5.1 \%, \mathrm{n}=6)$. The species $/$ water mass associations predicted using the SST and SSS optima from the coarse-scale analysis did not match the observed pattern for most of the species (Table 5).

\section{DISCUSSION}

\section{Environmental relationships}

During spring and autumn, SST was an important component of the environmental axes at the coarse scale. During spring, SSS was an important component of the canonical environmental axes, while during autumn, TD was important. Within a season and during the non-ENSO/LNSO years, species were consistently placed along different parts of the axes. This interannual consistency has been found at the coarse scale for seabird/habitat relationships in the Gulf of the Farallones, California (Allen 1994). Our results for individual species are consistent with earlier findings in the tropical Pacific. King (1970), who conducted work west of our study area, noted that Leach's stormpetrels were most abundant at low air and water temperatures and that sooty terns and black-winged petrels were most abundant in warmer waters. However, in contrast to our findings, King (1970) did not find any relationships with SSS.

Ballance (1993), specifically focusing on feeding flocks, found that sooty tern flocks were associated with the deepest thermoclines (similar to our findings in the autumn for sooty tern) and that Juan Fernandez petrel and wedge-tailed shearwater flocks were associated with thermoclines on average $78.5 \mathrm{~m}$ deep (consistent with our findings of Juan Fernandez petrels in autumn). In our study, TD was most important during the autumn, when the thermocline was the strongest (Fiedler 1992).

Ballance et al. (1997) argued that TD can be used as a surrogate for productivity. If so, then we found that seabirds were associated with different levels of productivity during the autumn. Autumn is considered to be the oceanographic 'summer' (Reilly 1990) when the thermocline is the strongest and productivity is greatest (Fiedler 1992). During the spring, the thermocline is not as strong so seabirds may be using other cues, such as SST and SSS, for staying in particular areas. Seabird associations with SST (in particular) and SSS have been noted in all the world's oceans regardless of spatial scale and these variables are typically assumed to be indicators of productivity (Ashmole 1971, Brown 1980).

When SST and SSS were the important components of the coarse-scale environmental axis, we could predict, for each year, the large-scale water mass with which a species should be associated using SST and SSS optima. However, we found little between-year consistency in the species associations with the largescale water masses. Our results at the large-scale suggest that seabirds are associated most consistently with current systems rather than water masses in the eastern tropical Pacific, regardless of season. Though a variety of species were found more often in the South Equatorial Current, in general, they did not differentiate between the 2 water masses contained within the current (see also Au \& Pitman 1986, Pitman 1986). Variability in relationships between seabird species and water masses has been noted by others. Working at smaller scales than our study, Abrams \& Griffiths (1981), Haney (1986), and Elphick \& Hunt (1993) found inconsistent (between-year) relationships of seabirds with water masses while Schneider et al. (1986) found consistent relationhips. The researchers who found inconsistent (between-year) relationships hypothesized that variability in seabird-water mass associations was a function of prey availability. This may also be true for our study (our analysis of seabird diet is pending), but changes in productivity would not explain why we found consistent associations with current systems.

Some of the difference may be due to characteristics of water masses and currents in the eastern tropical

Fig. 5. Biplots from canonical correspondence analysis for autumn (a) 1984, (b) 1985, (c) 1986, (d) 1987, (e) 1988, (f) 1989, (g) 1990, and (h) 1991. All variables are standardized to have zero mean and unit vanance; therefore, axes are in standard deviation units. Scores for the environmental variables are presented as arrows, the length of which indicates the importance of the variable to the habitat axis. Species scores (represented by the 4-letter codes) are measures of the centers of the species distribution along the environmental axis. Species codes are in Appendix 1 
(a)

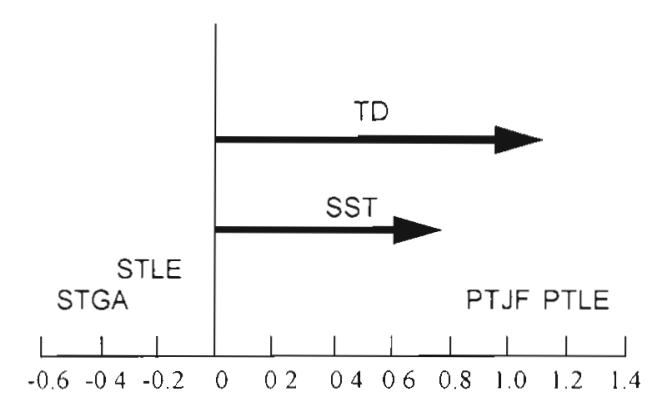

(c)

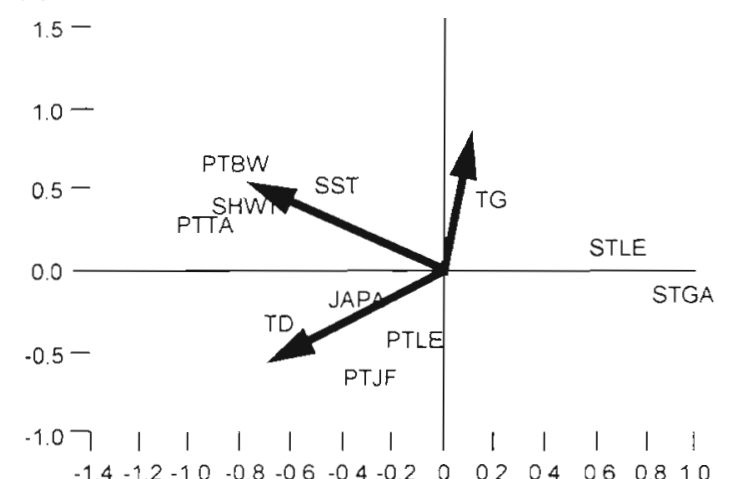

(e)

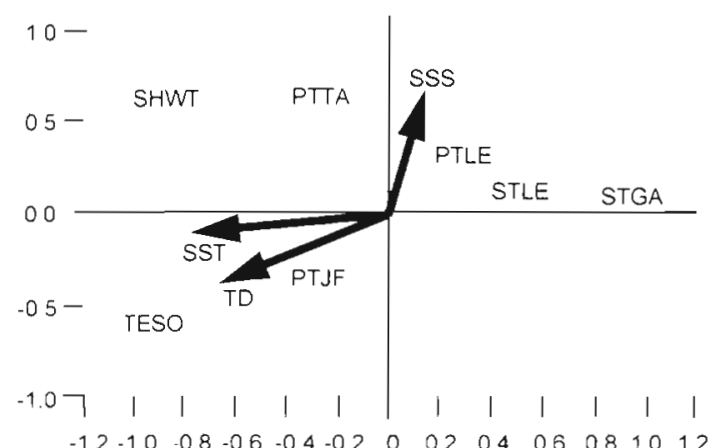

(g)

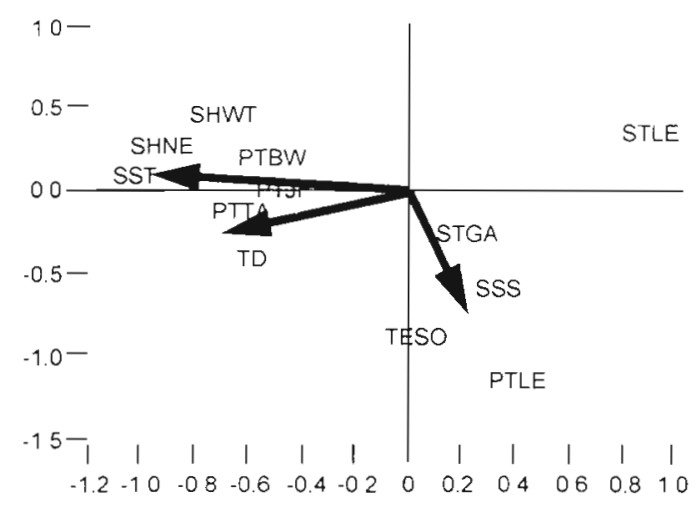

(b)

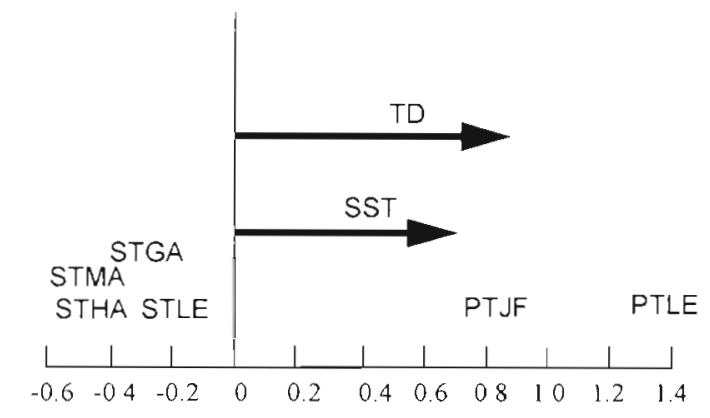

(d)

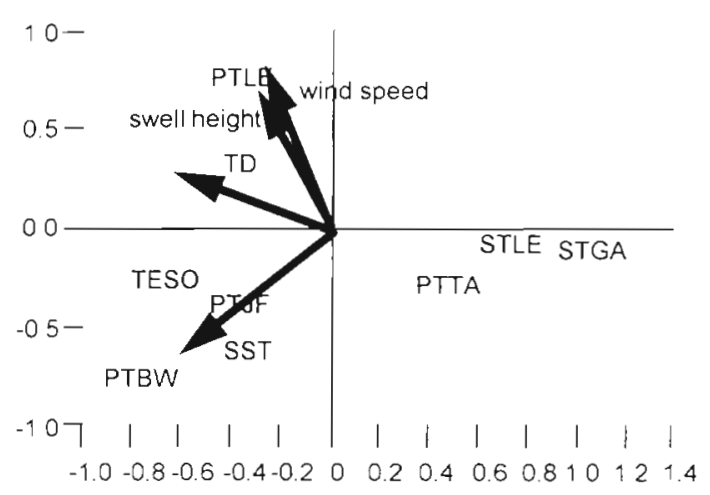

(f)

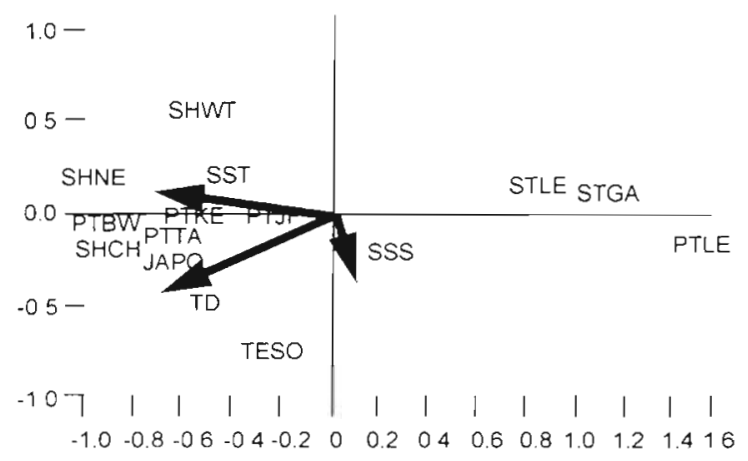

(h)

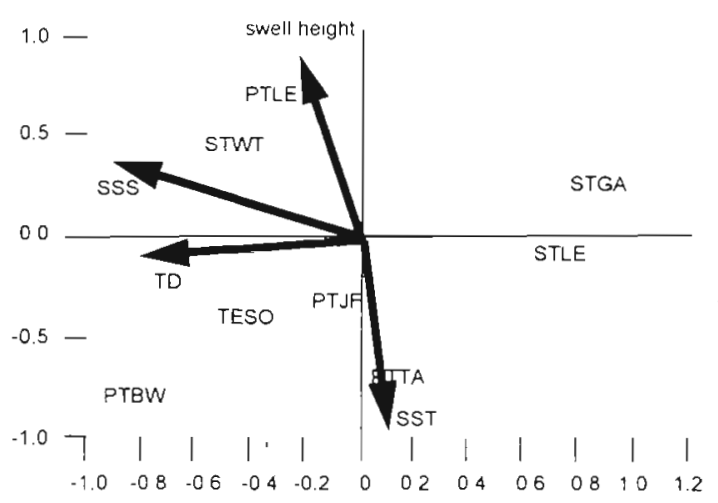


(a)

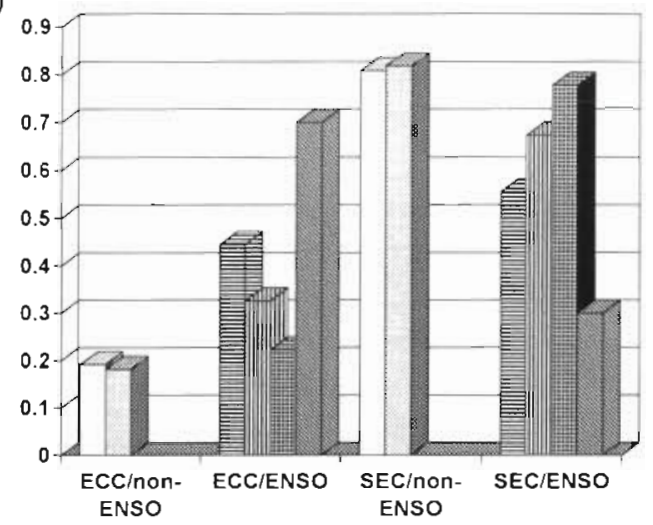

(c)

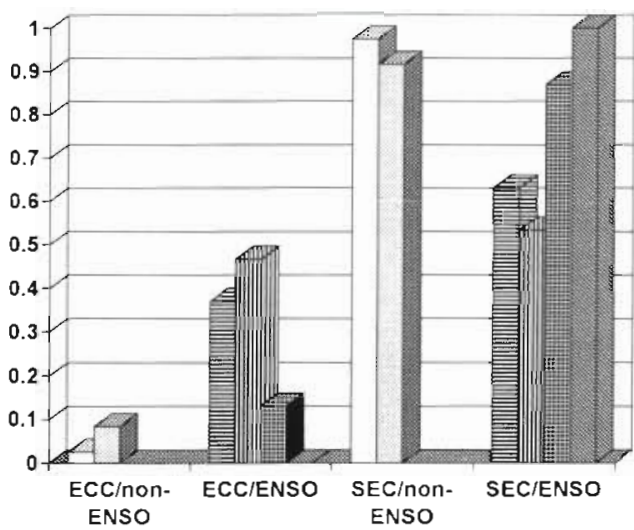

(e)

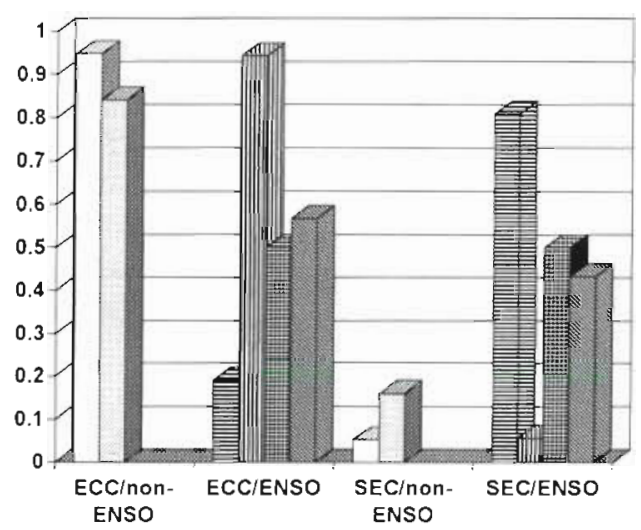

(g)

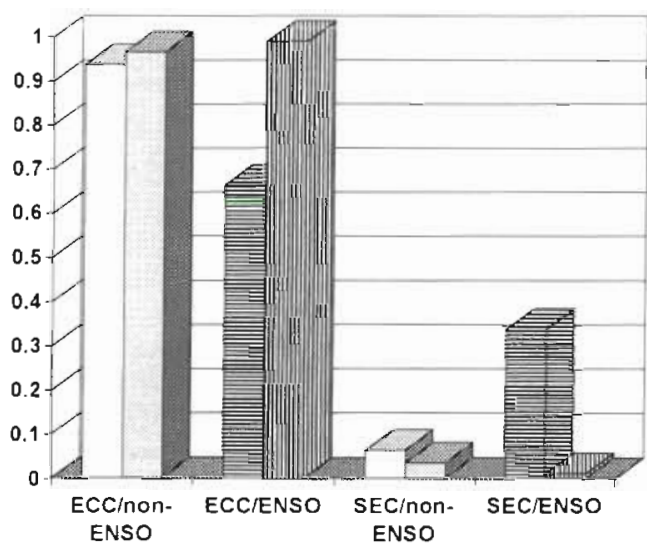

(b)

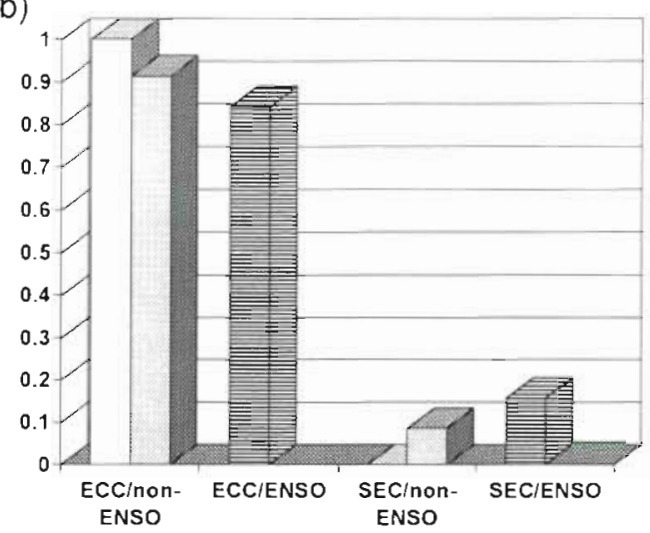

(d)

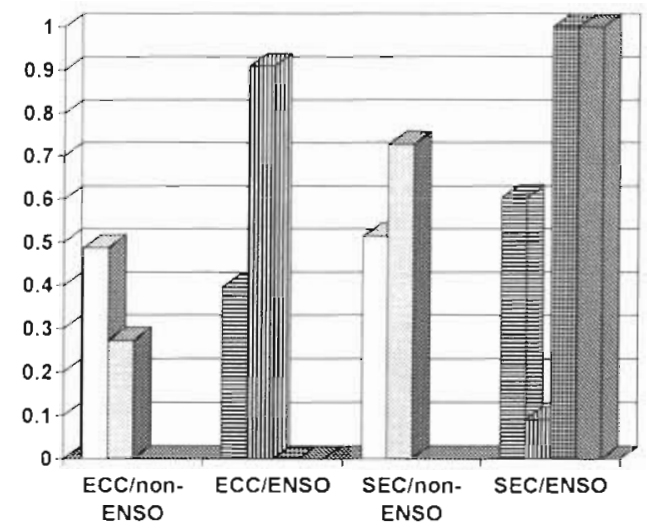

(f)

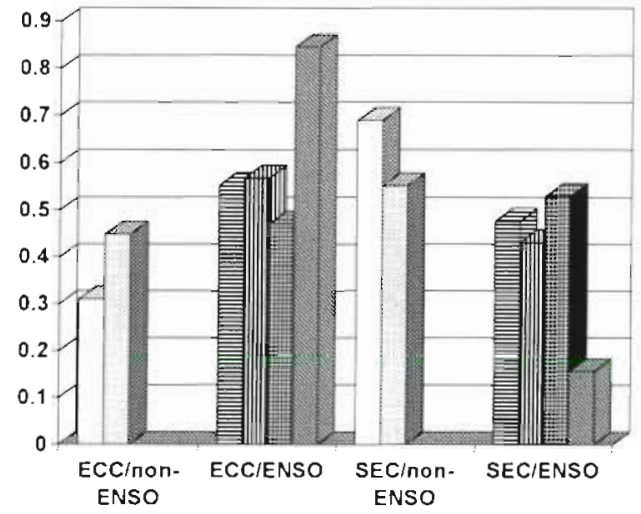

Fig. 6 Proportion of occurrence by current system and by nonENSO/LNSO and ENSO/LNSO years for 7 species seen on the autumn cruises: (a) wedge-rumped storm-petrel, (b) black-winged petrel, (c) white-winged petrel, (d) sooty tern, (e) Juan Fernandez petrel, (f) Leach's storm-petrel, and (g) wedge-tailed shearwater. The $y$-axis is proportion of individuals of the species that fell into the Equatorial Countercurrent (ECC) or the Southern Equatorial Current (SEC). The 'non-ENSO' designation on the $x$-axis indicates the data are from the cruises where neither an ENSO nor an LNSO occurred. The 'ENSO' designation on the $x$-axis indicates that the data are from the cruises that occurred during an ENSO or LNSO. The different shadings indicate different cruises within a category. The shadings for the ECC/non-ENSO and SEC/non-ENSO categories correspond (e.g. the white bar is the same cruise for those 2 categories). The shadings for the ECC/ENSO and SEC/ENSO categones also correspond (e.g. the same shaded bar is the same cruise for the 2 categories! 
(a)

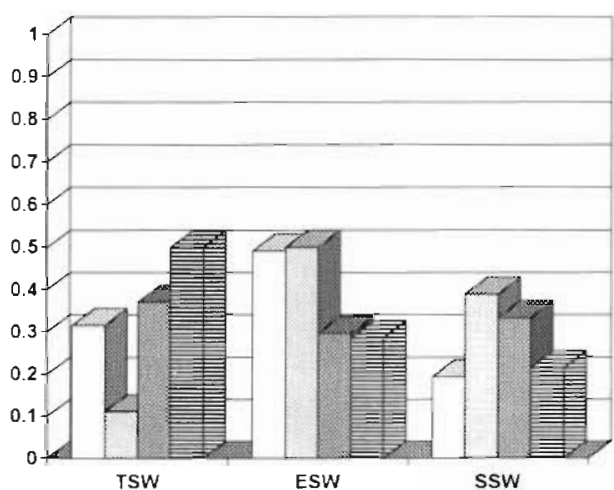

(c)

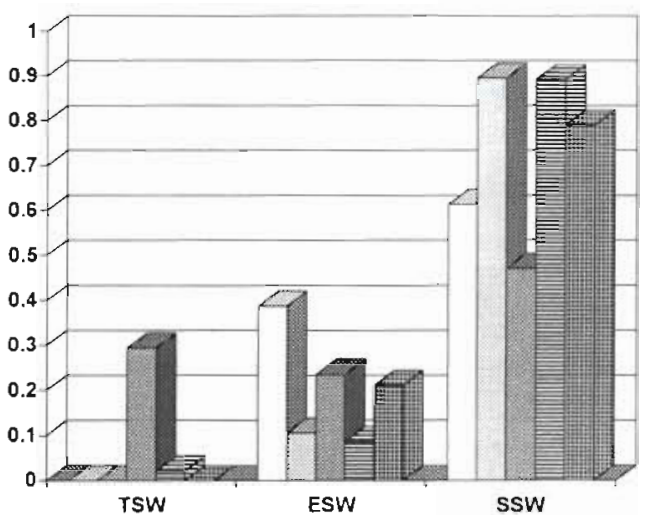

(e)

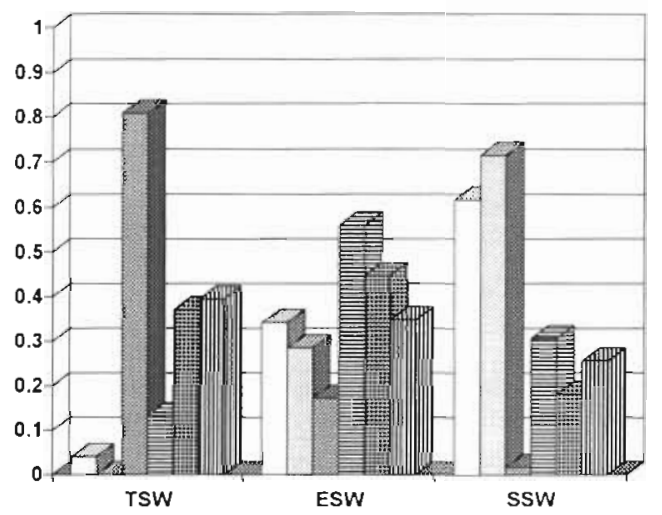

(g)

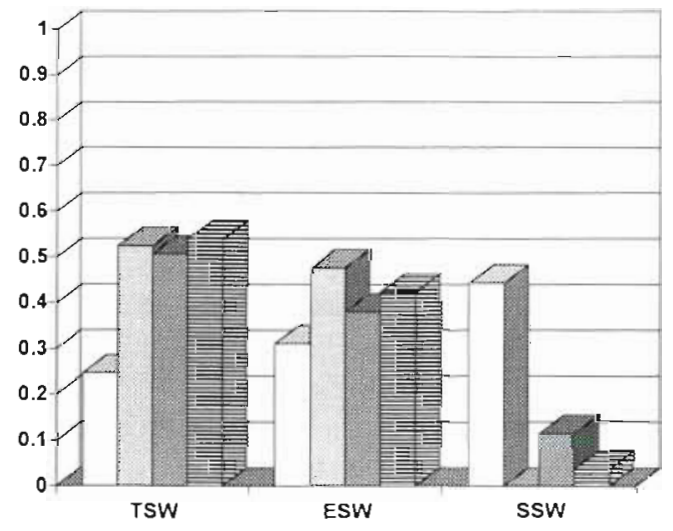

(b)

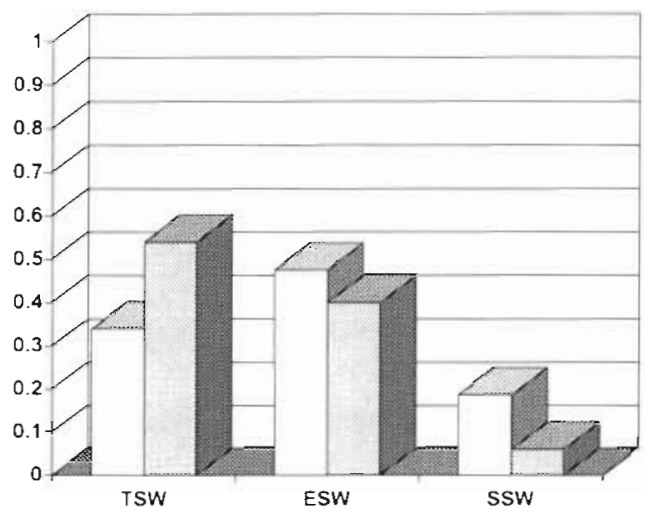

(d)

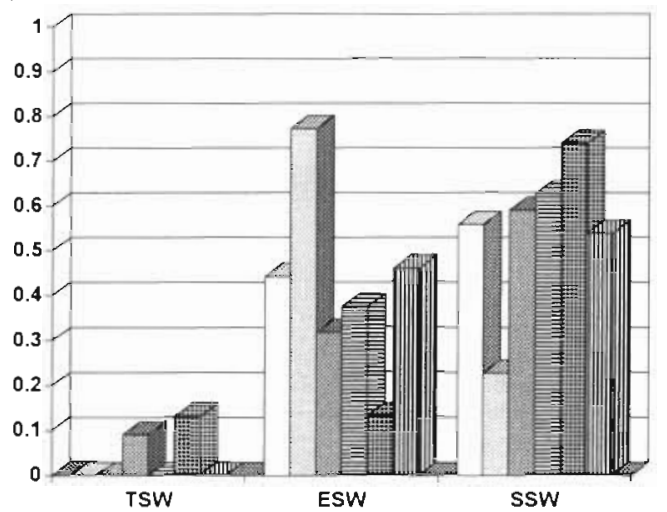

(f)

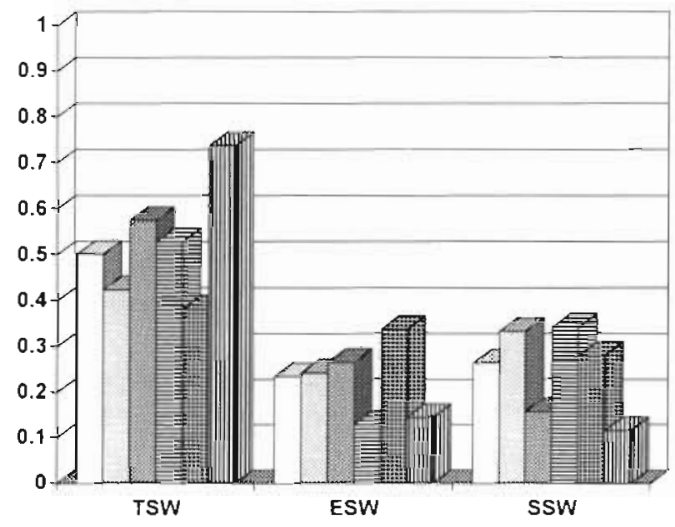

Fig. 7 Proportion of occurrence by water mass for 7 species seen on the autumn cruises: (a) wedge-rumped storm-petrel, (b) blackwinged petrel, (c) white-winged petrel, (d) sooty tern, (e) Juan Fernandez petrel, (f) Leach's storm-petrel, and (g) wedge-tailed shearwater. The $y$-axis is proportion of individuals of the species that fell into the Tropical Surface Water mass (TSW), the Equatorial Surface Water mass (ESW), and the Subtropical Surface Water mass (SSW). The shading for the water masses correspond (e.g. the white bar is the same cruise for the 3 water masses) 
Pacific compared to other areas. The boundaries between water masses in our study area do not coincide with sharp discontinuities such as fronts (Wyrtki 1966); this is different from other areas of the world ocean where changes in water masses important to seabirds are associated with frontal discontinuities (see review by Hunt 1990). Schneider et al. (1987) found that seabird associations with fronts was related to the strength of the gradient and Elphick \& Hunt (1993) hypothesized that the strength of the discontinuity may determine whether or not seabirds perceive differences between features. Past seabird studies in the eastern tropical Pacific have noted that seabird densities increased at the convergence between the North Equatorial Current and Equatorial Countercurrent, an area with a strong TG (King \& Pyle 1957, Ashmole \& Ashmole 1967, Gould 1974, King 1974, Spear et al. 1995; also reviewed in Hunt \& Schneider 1987). In our study, currents were defined by discontinuities in the thermocline while water masses were defined by zonal differences in SST and SSS. Therefore, in the equatorial Pacific, the seabirds may not have perceived the water masses to be different habitats though they did perceive differences in currents.

\section{Effect of ENSO/LNSO}

The effect of ENSO/LNSO differed depending on the scale at which we considered the species-environmental relationships. At the coarse scale, most of the species in the spring and all of them in the autumn had the same relationships to the canonical environmental axes, regardless of whether the cruise occurred during an ENSO/LNSO event or not. Only when we looked at the large scale did we see some species changes during the ENSO/LNSO events. In particular, we found different current associations or no current associations for wedge-rumped storm-petrel, Leach's storm-petrel, and Juan Fernandez petrel during the ENSO/LNSO events for both seasons. Sooty tern, black-winged petrel, and white-winged petrel were consistently found in association with the South Equatorial Current. Ballance et al. (1997) argued that sooty tern was adapted to low productivity areas in the open ocean within the eastern tropical Pacific. The major effect of ENSO is to decrease productivity in areas normally of higher productivity; areas of low productivity would not be as drastically affected. Therefore species such as sooty tern, already adapted to low productivity conditions, would not find a decrease in productivity caused by ENSO/LNSO events much different from the norm, and the association between sooty tern and waters of lower productivity would remain unchanged. In contrast, species that are associated with higher productivity waters, such as the storm-petrels, would find areas typically of high productivity changed to lower productivity during the ENSO/LNSO events and would move to (relatively) higher productivity waters, leading to changes at the large scale. The coarse-scale relationships would not necessarily change as the storm-petrels would continue to seek the higher productivity waters. This difference in productivity was used by Ribic et al. (1992) to explain why genera like boobies (Sula spp.) were not seen during the cruises made during the ENSO/LNSO events (also see Anderson 1989).

Even though ENSO has been implicated in the variability seen in physical and planktonic features of the eastern tropical Pacific (Murray et al. 1994), most seabird species apparently were able to track coarsescale environmental variables and other large-scale features in the study area and respond consistently. This is similar to results from a previous study, which included a cruise made during the 1976 ENSO (Ribic \& Ainley 1988/89).

In the present study we focused on those common seabird species which previously we had found to be unaffected by ENSO with respect to community structure (Ribic et al. 1992). There were many other less common species that we could not evaluate due to low sample size within and between years. Our study area encompassed the edge of many of these species ranges (Ribic et al. 1992, Spear et al. 1995) and in order to address environmental variable associations and the effects of ENSO/LNSO, a larger portion of the Pacific basin would have to be considered. Spear et al. (1995) did this, finding no effects of ENSO/LNSO on the seabird associations with physical variables. ENSO/ LNSO events do affect seabird populations, particularly in terms of survival and breeding in tropical and mid-latitudes of the Pacific (e.g. Schreiber \& Schreiber 1984, Anderson 1989, Ainley \& Boekelheide 1990), as well as spatial distribution and density at sea in coastal upwelling systems at mid-latitudes (Veit et al. 1996, 1997). However, we have found that ENSO/LNSO does not disrupt the basic relationships between seabirds and physical environmental variables at the coarse and large scales.

\section{Analysis techniques \\ Coarse-scale analysis}

We used canonical correlation analyses to investigate seabird-environmental variable relationships that are found in common among a large number of species at the coarse scale. This technique has assumptions like all statistical techniques. In particular, the underlying model of the species-environmental relationship is 
a symmetrical unimodal nonmonotonic relationship (i.e. a Gaussian curve). We checked to be certain that we did indeed have unimodal relationships for the majority of species we used in the analysis. However, the number of half-hour transects where a species was not seen added considerably to the noise in the relationship, leading to less variance explained by the analysis than perhaps we might want. In addition, the results will be influenced by the species with the largest number of sightings, since the unimodal model will be most appropriate for those species. This multispecies approach, then, sacrifices details on individual species to look at overall patterns across all species. An alternative approach would be to take an individual species approach as was done by Spear et al. (1995); this would give us many more details about individual species. For example, we looked at individual speciesenvironmental relationships for the spring cruises in conjunction with exploring the extent of seabird assemblage relationships to physical features (Ribic \& Ainley 1997). In that paper, in spring, sooty tern and wedge-rumped storm-petrel were found to be associated with TD as well as SSS. In this study, for these species, the relationship with TD was masked by a multivariate analysis looking at many species at once. Which viewpoint to take (i.e. multispecies versus individual species) depends upon the questions being posed. In this paper, we were more interested in overall patterns among many species rather than many details on individual species. Future work (Spear \& Ainley unpubl.) will take the single species approach using a larger portion of the Pacific basin that encompasses most of the individual species ranges.

Large-scale analysis

Another consideration is the use of contingency table analysis for the analysis of species in relation to water mass or current systems. Haney \& Solow (1992) suggest 2 analysis approaches, one based on counts (i.e. contingency table analysis) and the other based on density (i.e. analysis of variance). Though Haney \& Solow (1992) give different reasons for choosing one analysis technique over the other, the choice is probably more related to investigator preference since the 2 analysis techniques (contingency table analysis and analysis of variance) have been unified under the generalized linear model framework (McCullagh \& Nelder 1989). In either case, analysis will depend on how the samples (i.e. transects) are defined from the continuous records and checking the assumptions behind the tests. In our case, we checked for the effects of flocks, using an adjustment to the test statistic. However, in our study, many of the species we saw were not in flocks, but that is not the case everywhere. In other situations, it may be that the flock will need to be the unit of analysis and it will not be valid to use individual species at the large scale. Haney \& Solow (1992) have started the discussion of analysis of seabird data with their key to data analysis but there is a need for further dialogue on alternative analysis strategies.

Appendix 1. List of common names, scientific names and abbreviations (Abbr.) for the seabird species mentioned in the text. The abbreviations are used in Figs. 2 \& 3

\begin{tabular}{|c|c|c|}
\hline Common name & Scientific name & Abbr. \\
\hline Band-rumped storm-petrel & Oceanodroma castro & STHA \\
\hline Leach's storm-petrel & Oceanodroma leucorhoa & STLE \\
\hline Markham's storm-petrel & Oceanodroma markhami & STMA \\
\hline Wedge-rumped storm-petrel & Oceanodroma tethys & STGA \\
\hline White-faced storm-petrel & Pelagodroma marina & STWF \\
\hline White-throated storm-petrel & Nesofregetta fuliginosa & STWT \\
\hline Black-winged petrel & Pterodroma nigripennis & PTBW \\
\hline Bulwer's petrel & Bulweria bulwerii & PEBU \\
\hline Juan Fernandez petrel & Pterodroma externa & PTJF \\
\hline Kermadec petrel & Pterodroma neglecta & PTKE \\
\hline Phoenix petrel & Pterodroma alba & РТРH \\
\hline Pycroft's petrel & Pterodroma pycrofti & PTPY \\
\hline Tahiti petrel & Pterodroma rostrata & PTTA \\
\hline White-winged petrel & Pterodroma leucoptera & PTLE \\
\hline Sooty tern & Sterna fuscata & TESO \\
\hline White tern & Gygis alba & TEFA \\
\hline Christmas shearwater & Puffinus nativitatis & $\mathrm{SHCH}$ \\
\hline Newell's shearwater & Puffinus auricularis & SHNE \\
\hline Wedge-tailed shearwater & Puffinus pacificus & SHWT \\
\hline Parasitic jaeger & Stercorarius parasiticus & JAPA \\
\hline Pomarine jaeger & Stercorarius pomarinus & JAPO \\
\hline
\end{tabular}


Appendix 2. Summary statistics of the environmental variables for the half-hour transects on which the individual seabird species were sighted for spring 1984 to 1991 in the eastern tropical Pacific. n: number of transects on which the individual species was seen, the number before the / is the mean and the number after is the standard error. If a year is blank, the species was either not seen or seen on fewer than 10 half-hour transects

\begin{tabular}{|c|c|c|c|c|c|c|}
\hline Species & Year & $\mathrm{n}$ & Density (no. $\mathrm{km}^{-2}$ ) & $\operatorname{SST}\left({ }^{\circ} \mathrm{C}\right)$ & SSS (ppt) & Swell height (m) \\
\hline \multirow[t]{8}{*}{ Leach's storm-petrel } & 84 & 44 & $0.38 / 0.06$ & $26.7 / 0.1$ & $34.94 / 0.03$ & $1.9 / 0.1$ \\
\hline & 85 & 44 & $0.34 / 0.06$ & $26.2 / 0.2$ & $34.86 / 0.05$ & $1.1 / 0.1$ \\
\hline & 86 & 62 & $0.33 / 0.04$ & $26.9 / 0.2$ & $34.78 / 0.06$ & $1.4 / 0.1$ \\
\hline & 87 & 99 & $0.34 / 0.03$ & $28.7 / 0.1$ & $34.14 / 0.09$ & $1.4 / 0.02$ \\
\hline & 88 & 44 & $0.22 / 0.03$ & $24.1 / 0.3$ & $34.95 / 0.05$ & $1.2 / 0.04$ \\
\hline & 89 & 136 & $0.47 / 0.04$ & $26.7 / 0.1$ & $34.84 / 0.02$ & $1.4 / 0.02$ \\
\hline & 90 & 104 & $0.35 / 0.03$ & $28.0 / 0.1$ & $34.49 / 0.06$ & $1.2 / 0.03$ \\
\hline & 91 & 210 & $0.45 / 0.05$ & $27.6 / 0.1$ & $34.41 / 0.04$ & $3.7 / 1.0$ \\
\hline \multirow[t]{7}{*}{ Wedge-rumped storm-petrel } & $\begin{array}{l}84 \\
85\end{array}$ & 22 & $0.60 / 0.20$ & $26.9 / 0.2$ & $34.84 / 0.04$ & $1.6 / 0.07$ \\
\hline & 86 & 65 & $0.45 / 0.06$ & $26.0 / 0.1$ & $35.04 / 0.04$ & $1.6 / 0.1$ \\
\hline & 87 & 42 & $0.40 / 0.10$ & $28.7 / 0.1$ & $34.55 / 0.13$ & $1.4 / 0.04$ \\
\hline & 88 & 38 & $0.33 / 0.03$ & $23.5 / 0.3$ & $34.99 / 0.07$ & $1.2 / 0.1$ \\
\hline & 89 & 61 & $0.57 / 0.11$ & $26.1 / 0.1$ & $34.86 / 0.02$ & $1.1 / 0.1$ \\
\hline & 90 & 32 & $0.33 / 0.09$ & $28.3 / 0.2$ & $34.01 / 0.14$ & $1.0 / 0.1$ \\
\hline & 91 & 86 & $0.66 / 0.11$ & $27.1 / 0.1$ & $34.38 / 0.08$ & $0.8 / 0.1$ \\
\hline \multirow[t]{8}{*}{ Juan Fernandez petrel } & 84 & & & & & \\
\hline & 85 & 60 & $0.45 / 0.08$ & $26.7 / 0.1$ & $34.79 / 0.03$ & $1.2 / 0.1$ \\
\hline & 86 & 68 & $0.31 / 0.03$ & $26.2 / 0.1$ & $34.99 / 0.04$ & $1.5 / 0.04$ \\
\hline & 87 & 26 & $0.21 / 0.06$ & $28.4 / 0.1$ & $34.54 / 0.12$ & $1.5 / 0.03$ \\
\hline & 88 & 57 & $0.28 / 0.03$ & $25.2 / 0.3$ & $34.54 / 0.08$ & $1.3 / 0.04$ \\
\hline & 89 & 39 & $0.33 / 0.08$ & $27.2 / 0.1$ & $34.62 / 0.04$ & $1.3 / 0.1$ \\
\hline & 90 & 82 & $0.28 / 0.02$ & $27.7 / 0.1$ & $34.66 / 0.06$ & $1.3 / 0.03$ \\
\hline & 91 & 81 & $0.22 / 0.02$ & $27.0 / 0.1$ & $34.73 / 0.04$ & $0.9 / 0.1$ \\
\hline \multirow[t]{8}{*}{ Wedge-tailed shearwater } & 84 & 13 & $0.19 / 0.05$ & $26.7 / 0.2$ & $35.02 / 0.03$ & $2.1 / 0.1$ \\
\hline & 85 & 37 & $0.40 / 0.15$ & $26.8 / 0.1$ & $34.88 / 0.05$ & $1.0 / 0.1$ \\
\hline & 86 & 18 & $0.99 / 0.64$ & $27.3 / 0.2$ & $34.92 / 0.11$ & $1.8 / 0.1$ \\
\hline & 87 & 13 & $0.33 / 0.11$ & $28.4 / 0.1$ & $35.04 / 0.06$ & $1.5 / 0$ \\
\hline & 88 & 26 & $0.62 / 0.38$ & $27.4 / 0.2$ & $34.29 / 0.08$ & $1.2 / 0.1$ \\
\hline & 89 & 76 & $0.66 / 0.14$ & $27.2 / 0.1$ & $34.61 / 0.03$ & $1.4 / 0.1$ \\
\hline & 90 & 69 & $0.64 / 0.14$ & $28.0 / 0.1$ & $34.51 / 0.05$ & $1.2 / 0.03$ \\
\hline & 91 & 95 & $0.36 / 0.05$ & $27.7 / 0.1$ & $34.54 / 0.05$ & $1.4 / 0.1$ \\
\hline \multirow[t]{8}{*}{ Sooty tern } & 84 & & & & & \\
\hline & 85 & 13 & $1.38 / 0.64$ & $27.1 / 0.2$ & $34.96 / 0.09$ & $0.9 / 0.1$ \\
\hline & 86 & 23 & $1.30 / 0.46$ & $27.0 / 0.1$ & $35.11 / 0.04$ & $1.8 / 0.1$ \\
\hline & 87 & 23 & $0.19 / 0.03$ & $28.1 / 0.1$ & $34.76 / 0.05$ & $1.5 / 0$ \\
\hline & 88 & & & & & \\
\hline & 89 & & & & & \\
\hline & 90 & 33 & $3.08 / 1.00$ & $27.4 / 0.1$ & $35.02 / 0.04$ & $1.4 / 0.04$ \\
\hline & 91 & 123 & $1.61 / 0.23$ & $27.7 / 0.1$ & $34.77 / 0.03$ & $1.6 / 0.1$ \\
\hline \multirow[t]{8}{*}{ White-winged petrel } & 84 & & & & & \\
\hline & 85 & 20 & $0.17 / 0.04$ & $25.8 / 0.1$ & $35.09 / 0.01$ & $1.5 / 0.1$ \\
\hline & 86 & 23 & $0.25 / 0.03$ & $26.3 / 0.2$ & $35.02 / 0.06$ & $1.7 / 0.1$ \\
\hline & 87 & 22 & $0.19 / 0.03$ & $27.9 / 0.1$ & $34.76 / 0.05$ & $1.5 / 0$ \\
\hline & 88 & 53 & $0.32 / 0.04$ & $23.0 / 0.2$ & $35.02 / 0.05$ & $1.3 / 0.04$ \\
\hline & 89 & & & & & \\
\hline & 90 & 12 & $0.13 / 0.02$ & $27.1 / 0.1$ & $35.11 / 0.10$ & $1.4 / 0.1$ \\
\hline & 91 & 24 & $0.18 / 0.03$ & $26.9 / 0.1$ & $34.84 / 0.07$ & $0.9 / 0.1$ \\
\hline \multirow[t]{8}{*}{ Black-winged petrel } & 84 & & & & & \\
\hline & 85 & & & & & \\
\hline & 86 & 91 & $0.35 / 0.04$ & $26.0 / 0.1$ & $35.10 / 0.03$ & $1.6 / 0.04$ \\
\hline & 87 & 31 & $0.19 / 0.03$ & $27.8 / 0.1$ & $34.80 / 0.05$ & $1.5 / 0$ \\
\hline & 88 & 40 & $0.25 / 0.02$ & $25.6 / 0.4$ & $34.76 / 0.06$ & $1.0 / 0.1$ \\
\hline & 89 & 21 & $0.30 / 0.04$ & $27.1 / 0.1$ & $35.16 / 0.07$ & $1.7 / 0.1$ \\
\hline & 90 & 28 & $0.42 / 0.13$ & $27.2 / 0.1$ & $35.04 / 0.07$ & $1.4 / 0.03$ \\
\hline & 91 & 57 & $0.17 / 0.02$ & $27.1 / 0.1$ & $35.02 / 0.03$ & $1.6 / 0.7$ \\
\hline
\end{tabular}


Appendix 3. Summary statistics of the environmental variables for the transects on which the individual seabird species were sighted for autumn 1984 to 1991 in the eastern tropical Pacific. n: number of half-hour transects on which the individual species was seen, the number before the / is the mean and the number after is the standard error. If a year is blank, the species was either not seen or seen on fewer than 10 half-hour transects

\begin{tabular}{|c|c|c|c|c|c|c|}
\hline Species & Year & $\mathrm{n}$ & Density (no. $\mathrm{km}^{-2}$ ) & $\operatorname{SST}\left({ }^{\circ} \mathrm{C}\right)$ & SSS (ppt) & $\mathrm{TD}(\mathrm{m})$ \\
\hline \multirow[t]{8}{*}{ Leach's storm-petrel } & 84 & 51 & $0.35 / 0.06$ & $22.3 / 0.2$ & $34.73 / 0.04$ & $23.2 / 2.3$ \\
\hline & 85 & 52 & $0.53 / 0.09$ & $21.3 / 0.3$ & $34.78 / 0.03$ & $31.0 / 2.1$ \\
\hline & 86 & 170 & $0.49 / 0.04$ & $26.0 / 0.1$ & $34.67 / 0.05$ & $79.2 / 2.0$ \\
\hline & 87 & 62 & $0.30 / 0.03$ & $25.9 / 0.2$ & $34.79 / 0.07$ & $54.8 / 2.3$ \\
\hline & 88 & 108 & $0.46 / 0.05$ & $23.4 / 0.2$ & $34.58 / 0.05$ & $43.9 / 3.5$ \\
\hline & 89 & 178 & $0.44 / 0.03$ & $25.2 / 0.1$ & $34.68 / 0.05$ & $63.4 / 2.1$ \\
\hline & 90 & 197 & $0.52 / 0.04$ & $25.7 / 0.1$ & $34.58 / 0.04$ & $85.9 / 2.6$ \\
\hline & 91 & 79 & $0.32 / 0.04$ & $26.1 / 0.1$ & $34.70 / 0.09$ & $83.7 / 2.2$ \\
\hline \multirow[t]{8}{*}{ Wedge-rumped storm-petrel } & 84 & 38 & $0.38 / 0.08$ & $22.3 / 0.3$ & $34.70 / 0.05$ & $23.3 / 2.6$ \\
\hline & 85 & 44 & $0.75 / 0.14$ & $21.3 / 0.3$ & $34.77 / 0.04$ & $36.9 / 2.8$ \\
\hline & 86 & 63 & $0.15 / 0.04$ & $25.7 / 0.1$ & $34.59 / 0.07$ & $77.2 / 3.2$ \\
\hline & 87 & 32 & $0.39 / 0.09$ & $25.8 / 0.2$ & $34.80 / 0.08$ & $53.1 / 3.5$ \\
\hline & 88 & 50 & $0.20 / 0.03$ & $22.3 / 0.2$ & $34.63 / 0.05$ & $36.7 / 5.0$ \\
\hline & 89 & 24 & $0.15 / 0.02$ & $24.7 / 0.3$ & $34.81 / 0.12$ & $61.5 / 4.3$ \\
\hline & 90 & 20 & $0.24 / 0.05$ & $26.0 / 0.3$ & $34.74 / 0.13$ & $92.3 / 7.7$ \\
\hline & 91 & 19 & $0.23 / 0.04$ & $25.6 / 0.3$ & $34.83 / 0.14$ & $80.4 / 5.3$ \\
\hline \multirow[t]{8}{*}{ Juan Fernandez petrel } & 84 & 23 & $0.19 / 0.03$ & $23.3 / 0.2$ & $34.82 / 0.04$ & $34.7 / 2.6$ \\
\hline & 85 & 19 & $0.14 / 0.02$ & $23.1 / 0.3$ & $34.86 / 0.06$ & $35.3 / 6.7$ \\
\hline & 86 & 81 & $0.35 / 0.05$ & $26.4 / 0.1$ & $34.89 / 0.04$ & $98.6 / 1.7$ \\
\hline & 87 & 65 & $0.25 / 0.03$ & $26.7 / 0.1$ & $34.88 / 0.04$ & $64.7 / 2.8$ \\
\hline & 88 & 82 & $0.37 / 0.06$ & $24.6 / 0.2$ & $34.46 / 0.05$ & $58.0 / 4.4$ \\
\hline & 89 & 136 & $0.45 / 0.04$ & $26.7 / 0.1$ & $34.60 / 0.04$ & $83.2 / 3.1$ \\
\hline & 90 & 121 & $0.43 / 0.06$ & $27.1 / 0.1$ & $34.62 / 0.06$ & $111.1 / 2.3$ \\
\hline & 91 & 87 & $0.24 / 0.02$ & $26.1 / 0.1$ & $34.79 / 0.08$ & $85.8 / 2.3$ \\
\hline \multirow[t]{8}{*}{ White-winged petrel } & 84 & 23 & $0.18 / 0.03$ & $23.7 / 0.3$ & $34.88 / 0.05$ & $39.0 / 2.1$ \\
\hline & 85 & 36 & $0.25 / 0.04$ & $24.9 / 0.2$ & $35.03 / 0.04$ & $71.3 / 3.9$ \\
\hline & 86 & 67 & $0.18 / 0.02$ & $25.9 / 0.2$ & $34.95 / 0.03$ & $96.9 / 2.2$ \\
\hline & 87 & 61 & $0.26 / 0.03$ & $25.9 / 0.1$ & $35.09 / 0.04$ & $63.1 / 2.3$ \\
\hline & 88 & 33 & $0.17 / 0.03$ & $23.4 / 0.4$ & $34.79 / 0.09$ & $51.6 / 7.8$ \\
\hline & 89 & 30 & $0.15 / 0.02$ & $23.6 / 0.2$ & $35.12 / 0.02$ & $59.3 / 3.4$ \\
\hline & 90 & 55 & $0.29 / 0.05$ & $26.2 / 0.1$ & $35.21 / 0.04$ & $108.4 / 2.3$ \\
\hline & 91 & 76 & $0.29 / 0.03$ & $25.6 / 0.1$ & $35.10 / 0.02$ & $89.0 / 1.5$ \\
\hline \multirow[t]{8}{*}{ Black-winged petrel } & 84 & & & & & \\
\hline & 85 & & & & & \\
\hline & 86 & 47 & $0.39 / 0.06$ & $27.8 / 0.1$ & $34.70 / 0.07$ & $96.4 / 3.5$ \\
\hline & 87 & 12 & $0.11 / 0.01$ & $27.7 / 0.2$ & $35.00 / 0.05$ & $68.4 / 7.9$ \\
\hline & 88 & & & & & \\
\hline & 89 & 33 & $0.18 / 0.03$ & $27.3 / 0.1$ & $34.66 / 0.06$ & $93.6 / 6.1$ \\
\hline & 90 & 71 & $0.25 / 0.03$ & $27.5 / 0.1$ & $34.48 / 0.07$ & $117.3 / 2.7$ \\
\hline & 91 & 10 & $0.16 / 0.02$ & $26.8 / 0.2$ & $35.04 / 0.04$ & $101.2 / 3.5$ \\
\hline \multirow[t]{8}{*}{ Sooty tern } & 84 & & & & & \\
\hline & 85 & & & & & \\
\hline & 86 & 40 & $1.31 / 0.29$ & $26.9 / 0.2$ & $34.90 / 0.04$ & $100.8 / 2.4$ \\
\hline & 87 & 20 & $0.87 / 0.32$ & $26.4 / 0.2$ & $35.04 / 0.05$ & $69.7 / 5.1$ \\
\hline & 88 & 14 & $0.64 / 0.24$ & $25.8 / 0.2$ & $34.67 / 0.14$ & $88.2 / 8.6$ \\
\hline & 89 & 58 & $1.17 / 0.26$ & $26.7 / 0.2$ & $34.79 / 0.05$ & $89.9 / 4.2$ \\
\hline & 90 & 42 & $1.08 / 0.34$ & $26.4 / 0.2$ & $34.92 / 0.08$ & $102.7 / 4.9$ \\
\hline & 91 & 20 & $0.73 / 0.20$ & $25.8 / 0.2$ & $35.04 / 0.04$ & $93.7 / 1.8$ \\
\hline
\end{tabular}

Acknowledgements. We thank the officers and crews of the NOAA 'Discoverer' and 'Oceanographer', and personnel of the Pacific and Atlantic Marine Environmental Laboratories of NOAA who allowed our participation on their cruises and facilitated our efforts. Many people assisted us at sea. We are especially grateful to lan Gaffney, Steve Howell, Nina Karnovsky, Peter Pyle, and Sophie Webb for repeatedly volunteering. Our project was funded by the National Science Foundation, Division of Biological Oceanography (grants OCE-8515637,-8911125) and National Geographic Society $(3321-86,-89)$. We thank L. Ballance, K. Daly, E. Woehler, D. Schneider, and 2 anonymous reviewers for helpful comments on previous versions of this manuscript. 


\section{LITERATURE CITED}

Abrams RW (1985) Environmental determinants of pelagic seaburd distribution in the African sector of the Southern Ocean. J Biogeogr 12:473-492

Abrams RW, Griffiths AM (1981) Ecological structure of the pelagic seabird community in the Benguela Current Region. Mar Ecol Prog Ser 5:269-277

Ainley DG, Boekelheide RJ (1983) An ecological comparison of oceanic seabird communities of the South Pacific Ocean. Stud Avian Biol 8:2-23

Ainley DG, Boekelheide RJ (1990) Seabirds of the Farallon Islands: dynamics of an upwelling-system community. Stanford Univ Press, Palo Alto, CA

Ainley DG, Ribic CA, Fraser WR (1994) Ecological structure among migrant and resident seabirds of the Scotia Weddell Confluence region. J Anim Ecol 63:347-364

Allen SG (1994) The distribution and abundance of marine birds and mammals in the Gulf of the Farallones and adjacent waters, 1985-1992. PhD dissertation, Univ California, Berkeley

Anderson DJ (1989) Differential responses of boobies and other seabirds in the Galapagos to the 1986-87 El NinoSouthern Oscillation event. Mar Ecol Prog Ser 52:209-216

Ashmole NP (1971) Seabird ecology and the marine environment. Avian Biol 1:223-286

Ashmole NP, Ashmole MJ (1967) Comparative feeding ecology of seabirds on a tropical oceanic island. Yale Univ Peabody Mus Nat Hist, Bull 24:1-131

Au DWK, Pitman RL (1986) Seabird interactions with dolphins and tuna in the Eastern Tropical Pacific. Condor 88: $304-417$

Au DW, Pitman RL (1988) Seabird relationships with tropical tunas and dolphins. In: Burger $J$ (ed) Seabirds and other marine vertebrates: competition, predation and other interactions. Columbia Univ Press, New York, p $174-209$

Ballance LT (1993) Community ecology and flight energetics in tropical seabirds of the Eastern Pacific: energetic correlates of guild structure. PhD dissertation, Univ California, Los Angeles

Ballance LT, Pitman RL, Reilly SB (1997) Seabird community structure along a productivity gradient: importance of competition and energetic constraint. Ecology 78 : $1502-1518$

Brown RGB (1980) Seabirds as marine animals. In: Burger J, Olla BL, Winn HE (eds) Behavior of marine animals, Vol 4 , Marine birds. Plenum Press, New York, p 1-39

Croxall JP (1987) Seabirds: feeding ecology and role in marine ecosystems. Cambridge Univ Press, Cambridge

Elphick CS, Hunt GL Jr (1993) Variations in the distributions of marine birds with water mass in the northern Bering Sea. Condor 95:33-44

Fiedler PC (1992) Seasonal climatologies and variability of eastern tropical Pacific surface waters. NOAA Tech Rep NMFS 109

Fiedler PC, Chavez FP, Behringer DW, Reilly SB (1992) Physical and biological effects of Los Niños in the eastern tropical Pacific, 1986-1989. Deep Sea Res 39:199-219

Fienberg SE (1980) The analysis of cross-classified categorical data, 2nd edn. The MIT Press, Cambridge, MA

Garson GI, Moser EB (1995) Aggregation and the Pearson chi-square statistic for homogeneous proportions and distributions in ecology. Ecology 76:2258-2269

Gittins R (1985) Canonical analysis. Springer-Verlag, New York

Gould PJ (1974) Sooty tern (Sterna fuscata). In: King WB (ed) Pelagic studies of seabirds in the central and eastern
Pacific Ocean. Smithsonian Instutution, Washington, DC p $6-52$

Haney JC (1986) Seabird segregation at Gulf Stream frontal eddies. Mar Ecol Prog Ser 28:279-285

Haney JC, Solow AR (1992) Analyzing quantitative relationships between seabirds and marine resource patches. In: Power DM (ed) Current ornithology, Vol 9. Plenum Press, New York, p 105-161

Hunt GL Jr (1990) The pelagic distribution of marine birds in a heterogeneous environment. Polar Res 8:43-54

Hunt GL Jr, Schneider DC (1987) Scale-dependent processes in the physical and biological environment of marine birds. In: Croxall JP (ed) Seabirds: feeding ecology and role in marine ecosystems. Cambridge Univ Press, Cambridge, $p 7-41$

Jongmann RH, ter Braak CJF, van Tongeren OFR (1987) Data analysis in community and landscape ecology. Pudoc, Wangeningen

King JE, Pyle RL (1957) Observations on sea birds in the tropical Pacific. Condor 59:27-39

King WB (1970) The trade wind zone oceanography pilot study, Part VII: observations of sea birds March 1964 to June 1965. US Fish Wildl Serv Spec Scient Rep Fish 586

King WB (ed) (1974) Pelagic studies of seabirds in the central and eastern Pacific Ocean. Smithsonian Institution, Washington, DC

Longhurst AR, Pauly D (1987) Ecology of tropical oceans. Academic Press, New York

Manly BFJ (1991) Randomization and Monte Carlo methods in biology. Chapman and Hall, New York

McCormick MI (1994) Comparison of field methods for measuring surface topography and their associations with a tropical reef fish assemblage. Mar Ecol Prog Ser 112 $87-96$

McCullagh P, Nelder JA (1989) Generalized linear models, 2nd edn. Chapman and Hall, New York

Murray JW, Barber RT, Roman MR, Bacon NW, Feely RA (1994) Physical and biological controls on carbon cycling in the equatorial Pacific. Science 266:58-65

Nettleship DN, Sanger GA, Springer PF (1985) Marine burds: their feeding ecology and commercial fisheries relationships. Canadian Wild Serv, Minister of Supply and Services, Ottawa

Norusis MJ (1988) SPSS/PC+ advanced statistics V2.0. SPSS Inc, Chicago

Numerical Algorithms Group (1987) The GLIM system release 3.77 manual, edition 2. Royal Statistical Soc, Oxford

Palmer MW (1993) Putting things in even better order: the advantages of canonical correspondence analysis. Ecology 74:2215-2230

Pitman RL (1986) Atlas of seabird distribution and relative abundance in the eastern Tropical Pacific. NMFS Southwest Fish Center Admin Rep LJ-86-02C

pocklington R (1979) An oceanographic interpretation of seabird distributions in the Indaan Ocean. Mar Biol 51: $9-21$

Reilly SB (1990) Seasonal changes in distribution and habitat differences among dolphins in the eastern tropical Pacific. Mar Ecol Prog Ser 66:1-11

Ribic CA, Ainley DG (1988/89) Constancy of seabird species assemblages: an exploratory look. Biol Oceanogr 6: 175-202

Ribic CA. Ainley DG (1997) The relationships of seabird assemblages to physical habitat features in Pacific equatorial waters during spring 1984-1991. ICES J Mar Sci (in press] 
Ribic CA, Ainley DG, Spear LB (1992) Effects of El Niño and La Niña on seabird assemblages in the Equatorial Pacific. Mar Ecol Prog Ser 80:109-124

Schneider DC, Harrison NM, Hunt GL (1987) Variation in the occurrence of marine birds at fronts in the Bering Sea. Estuar Coast Shelf Sci 25:135-141

Schneider DC, Hunt GL, Harrison NM (1986) Mass and energy transfer to seabirds in the southeastern Bering Sea. Cont Shelf Res 5:241-257

Schreiber RW, Schreiber EA (1984) Central Pacific seabirds and the El Niño Southern Oscillation: 1982 to 1983 perspective. Science 225:713-716

Spear LB, Ainley DG (1997) Flight speed of seabirds in relation to wind speed and direction. Ibis 139:234-251

Spear LB, Ainley DG, Nur N. Howell SNG (1995) Population size and factors affecting at-sea distributions of four endangered procellariids in the tropical Pacific. Condor $97: 613-638$

Spear L, Nur N, Ainley DG (1992) Estimating absolute densities of flying seabirds using analysis of relative movement. Auk 109:385-389

This article was presented by David Schneider (Senior Editorial Advisor), St. Johns, Newfoundiand, Canada ter Braak CJF (1988) CANOCO-a FORTRAN program for canonical community ordination by correspondence analysis, principal components analysis and redundancy analysis (version 2. 1). Groep Landbouwwiskunde Tech Rep LWA-88-02

ter Braak CJF (1990) Update notes: CANOCO version 3.10. Agricultural Mathematics Group Tech Rep

ter Braak CJF, Prentice IC (1988) A theory of gradient analysis. Adv Ecol Res 18:271-317

Veit RR, McGowan JA, Ainley DG, Wahl TR, Pyle P (1997) Apex marine predator declines ninety percent in association with changing ocean climate. Global Change Biology 3:23-28

Veit RR, Pyle P, McGowan JA (1996) Ocean warming and long-term change in pelagic bird abundance within the California current system. Mar Ecol Prog Ser 139: $11-18$

Wyrtki K (1966) Oceanography of the eastern equatorial Pacific Ocean. Oceanogr Mar Biol Ann Rev 4:33-68

Wyrtki K (1967) Circulation and water masses in the Eastern Equatorial Pacific Ocean. Int J Oceanol Limnol 1:117-147

Manuscript received: March 31, 1996

Revised version accepted: June 20,1997 